\title{
Safety of mining machinery drives - selected issues
}

\begin{abstract}
The machines used in contemporary mining work under extremely demanding environmental and working conditions, especially when variable loads occur during the mining and transport. This causes a dynamic load occurrence, particularly influencing the mechanical subunits of the machine drive system; the dynamic loads negatively affect the durability, reliability, and security of its use. Counteracting the negative results of the mutual dynamic interactions between the parts of the machine drive is helped by the application of appropriate methods and measures leading to diminished transferred dynamic loads. The specifics of the working conditions in mining machines causes high dynamic loads during electrical or mechanical starting. We present models of torsionally flexible couplings applied in mining machines having a reduction of the dynamic loads occurring during stabile work as a target.
\end{abstract}

Key words: protection, overload, drive system

\section{INTRODUCTION}

Basic mining machines working in underground coal mines are excavating machines that convey waste from the longwall. The nature of these machines makes them some of the most-exposed machines in the mining industry. This situation requires special attention to the process of their design and operation.

The basic mechanical unit that mediates the performance of each mining machine is the propulsion system. Its components usually include such elements as an electric motor, gears, couplings, and components or actuators in the form of a mining body (drill) or drum.

The main mechanical assemblies in the drive system of excavating and transporting machines (such as the couplings and gears) are subjected to particularly intensive variable-load operating forces with significant instantaneous high-frequency overloads that occur primarily in unsteady starters (scraper conveyors) as well as during fixed work. The ultimate effect of these adverse effects is reducing their reliability and durability. A remedy for such adverse operating conditions is to use special technical measures to protect the components of the drive system from overload. An example of this may be the drive system of a floor conveyor, where significant problems are associated with its start up. One way is to use a starter device to facilitate this process by electrical and/or mechanical means. As mentioned above, the overloads also occur during the operation of the fixed machine. In this case, torsionally flexible couplings of different designs are used.

In this article, an overview of the protection of the propulsion systems of selected mining machines is presented in a comprehensive and synthetic manner. The main focus is on a mechanical solution used in mining machine drive systems.

\section{PROTECTION OF DRIVE SYSTEM OF EXCAVATING MACHINES}

In the process of extracting hard coal, roadheaders and longwall shearers are used as mining machines for the excavation of waste.

Roadheaders are used for drilling the corridors that provide access to coal, salt, and copper ores. The individual working motions of the actuators are realized by means of drive mechanisms of the excavating body, crawler chassis, and excavator loader. 
The most-heavily-loaded is the propulsion system of the working heads. Admittedly, their start-up is usually without load, but there are high dynamic loads from the cutting of coal or stone by the knives. The instability of the mechanical parameters of the workmanship and method of moving the workpiece heads are the reason for the variable load in the drive system from the electric motor to the working heads. Figure 1 shows an example of the construction of an AM- $50 \mathrm{z}$ roadheader. Depending on the design of the mining machine, the reducer can take a different form in kinematic terms, but the coupler between the input shaft of the reducer and the motor is always a flexible coupler. In most cases, it is an insert coupling or, as in the case of the AM-50z roadheader, a finger coupling.

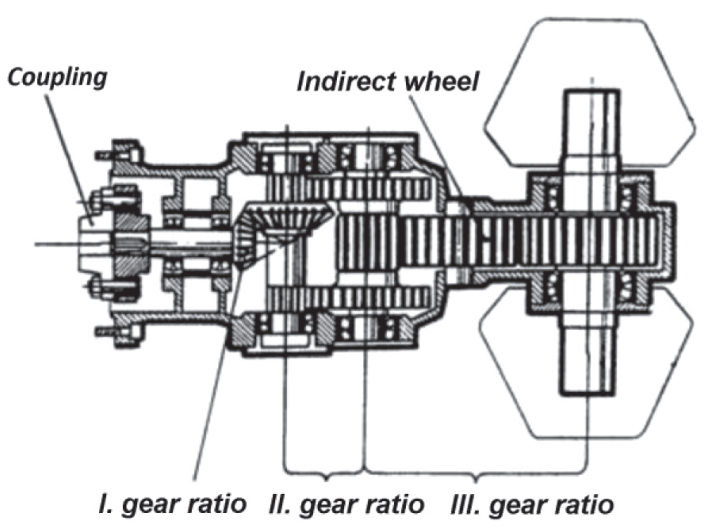

Fig. 1. Drive system of head of AM-50z roadheader [1]

This clutch is designed to alleviate the dynamic load on the transmission input shaft from the engine at startup and then relieve the load on the motor shaft from the response to the cutting load. Figure 2 shows the passive member of the insert coupling, and in Figure 3, the finger clutch of the longitudinal milling head is shown.

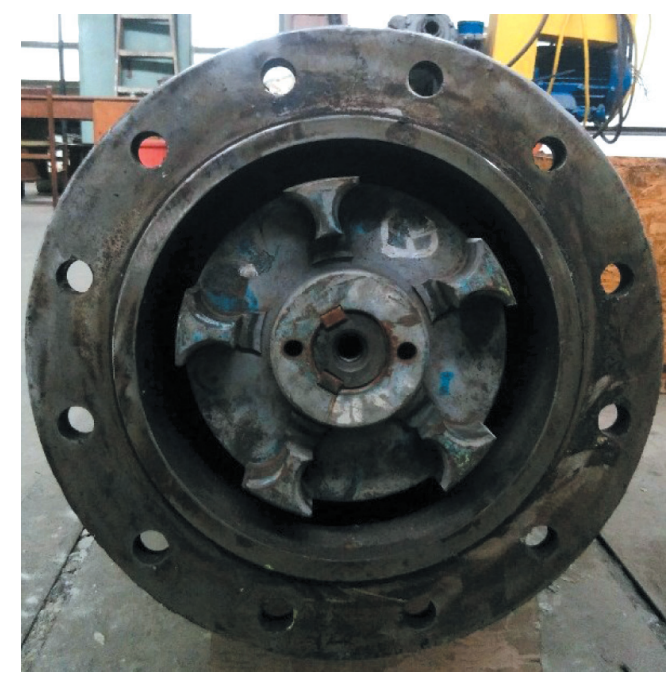

Fig. 2. View of passive member of insert clutch used in roadheader

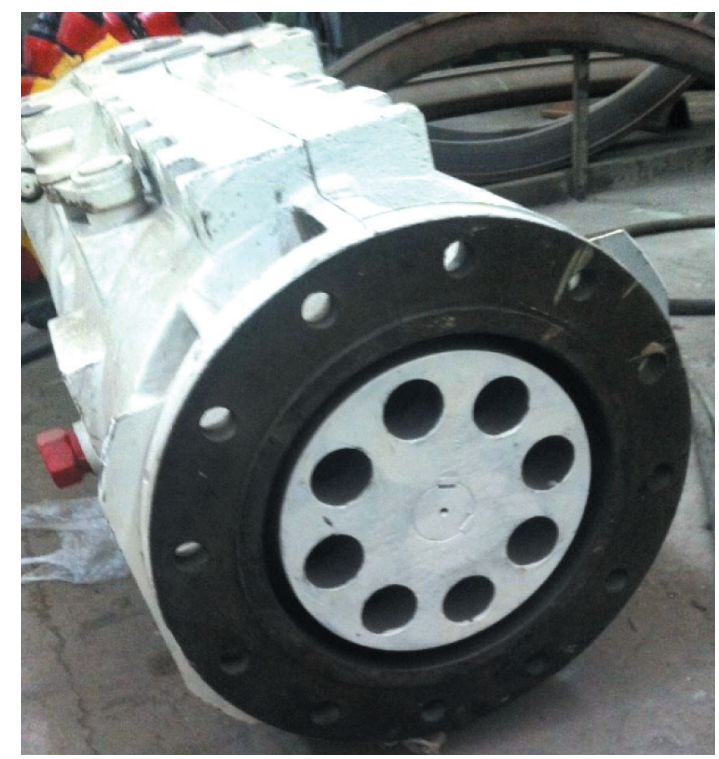

Fig. 3. View of passive member of finger clutch used in roadheader

In addition to the flexible coupling, friction clutches can also be used (as in the case of the AM-75 combine). It also functions as an overload clutch.

The overload protection in the shaping body is predominantly handled by the expansion ring (Fig. 4), by means of which the torque is transferred from the passive shaft of the reducer to the cutting head.

It is a combination of a cylindrical smooth hub of the cutting head with a cylindrical smooth output shaft [2]. When an overload occurs, the friction force in the ring is exceeded, and there is a slip and a break in the torque transmission.

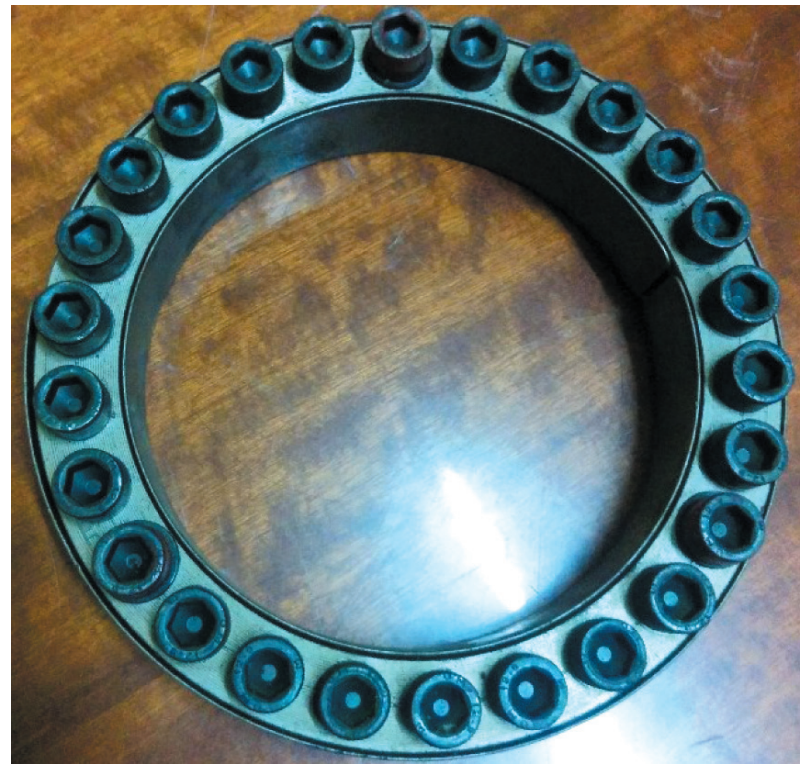

Fig. 4. View of expansion ring for use in head of mining roadheader 
In addition to the direct methods of securing the propulsion system of the digging machine in the roadheader against overload, indirect methods are used, which include [2]:

- thermal protection of the drive motor,

- limiting the clamping force of the cutting head as the pressure in the power supply of the boom tilting cylinders increases,

- limiting the speed of moving the cutting head as the power consumption of the engine in the cutting system increases.

Another machine used for the simultaneous excavation and loading of waste on the conveyor is a shearer. It forms part of the longwall complex. Figure 5 shows an exemplary view of a geometrical model of the drive system of the mining body.

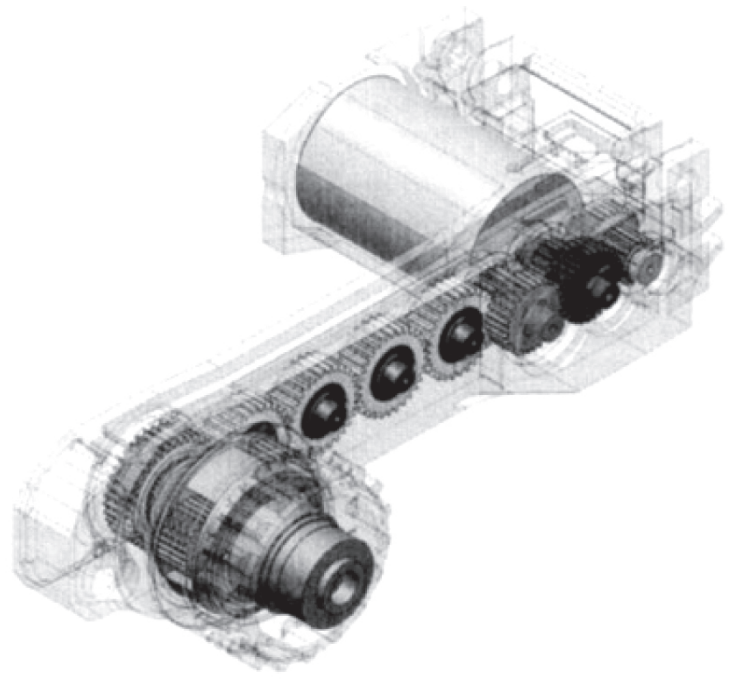

Fig. 5. Geometrical model of longwall shearer drive system [3]

The overload protection of the driveline can be achieved by direct and indirect drives. Indirect methods include all of the controls included in the harvester control system, such as the Joy's company Faceboss control system, where the engine parameters are controlled without blocking or overheating.

The highest load from coal mining is in the propulsion system of the mining body. It is true that the start-up process itself is not a problem (as it takes place without a load), but during the cutting process, there is a high degree of variability over time, and its intensity depends on the speed of the combine.

Protective gear assemblies for the drilling unit and overload drive may be fuse shafts that transmit the engine torque to the first gear stage $[4,5]$. This solution is used in the $\mathrm{KSW} 460$, KSW 620E, and KSW-1140E mining combines, for example. The fuse shaft has an undercut, and in the event of an overload in the drive system, it is destroyed there. This shaft is easily replaced by a new one.

\section{PROTECTION OF DRIVE SYSTEM OF TRANSPORTING MACHINES}

\subsection{Scraper conveyors}

Scraper conveyors are the beginning of the conveyor belt from the longwall. The operating conditions of the wall conveyor make them some of the heaviest operating conditions in underground mining. Considerable problems are caused by the start-up, mainly due to the mass of the excavated material on the route as well as too much initial tension on the chain and any problems on the supply side of the engine (the status of the mine network, incorrect drive order, etc.).

In addition to the difficult start-up, the main mechanisms of the drive system of the floor conveyor are exposed to particularly intensive operating loads in the form of variable loads with significant instantaneous overloads (also during steady-state operation).

Counteracting the unfavorable effects of the interference of the elements of the floor conveyor drive systems is possible through the use of appropriate methods and measures leading to the reduction of dynamic load transmission, as they have a significant impact on the development of degradation processes (especially fatigue).

As mentioned earlier, a big problem is the start-up of a loaded conveyor. This is particularly important because mine practice shows that the wall conveyor is switched on and off relatively frequently [6].

It is possible to start up the loaded conveyor by taking the appropriate technical measures. It can be carried out by electrical (the simplest solution is to use a two-speed motor) or mechanical means. The electric starter methods/devices are:

- contactor starters,

- thyristor units,

- frequency converters.

Enabling the start of the conveyor as well as limiting the negative effects of the interaction of the propulsion system components during the fixed operation 
is also possible through the use of simple torsionally flexible couplings and moreadvanced overload / start couplings construction.

At present time, in the mining scraper conveyors between the motor and gearbox, flexible couplings with elastomer or polyurethane inserts (Fig. 6) or two-component (Fig. 7) are often used.

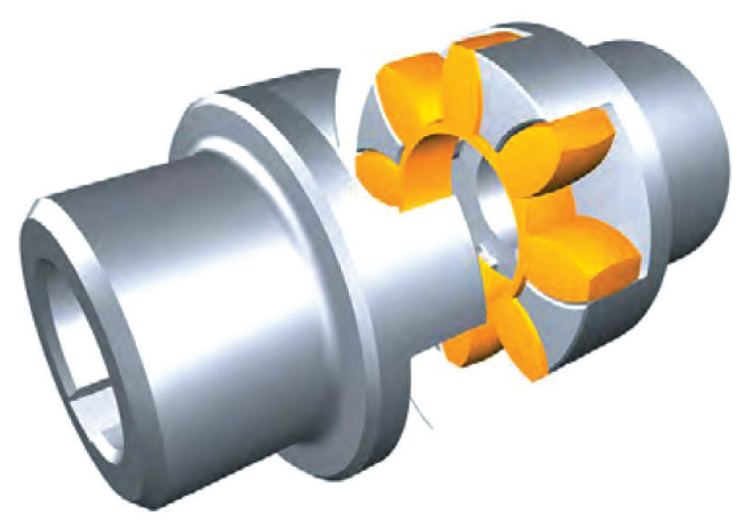

Fig. 6. One insert flexible coupling SP (ASR) [7, 8]

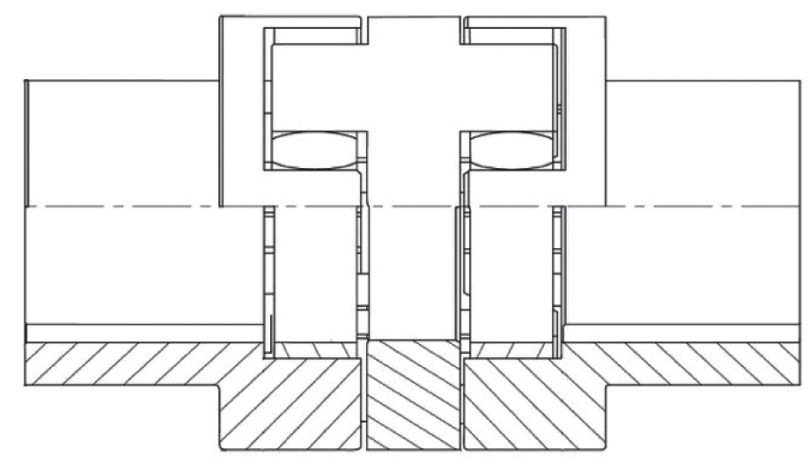

Fig. 7. Two insert flexible coupling SPP (ASR) [7]

In the floor conveyors, a connection of the flexible and overload couplings is also used. Figure 8 shows an example design of such a solution.

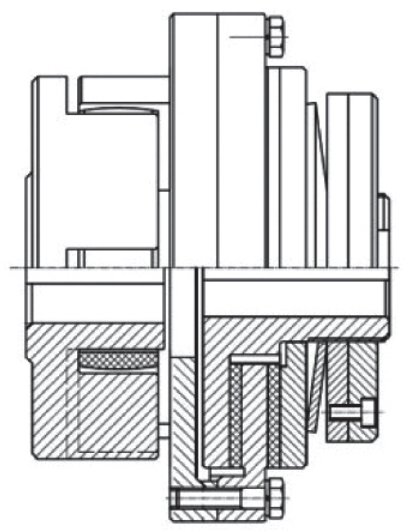

Fig. 8. Overload coupling APMX [8]
This is a typical insertion clutch with an adjustable torque value at which friction on the friction pads occurs and disconnects the drive.

Other couplings are also available. An example is the clutch, which is manufactured by RFM RYFAMA (Fig. 9), where the flexible element is a rubber torus in which the steel sleeves are vulcanized. In the bushes, there are alternating steel bolts attached to the discs located on the active and passive couplings [9].

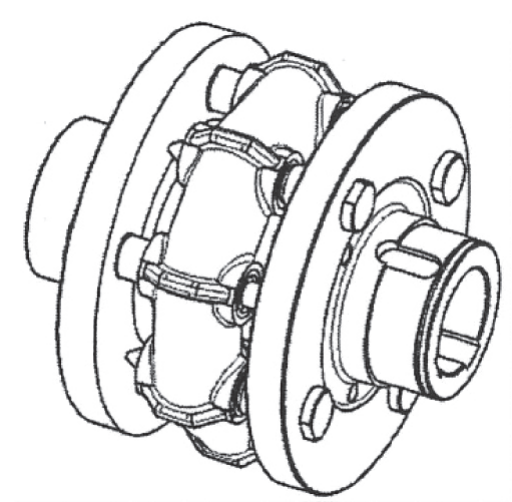

Fig. 9. Flexible coupling of RFM RYFAMA [9]

In turn, the original solution of the flexible coupler with removable elastic part (insert) without dismantling the engine is offered in the TZ Polska company. These are the BHDD and SDD clutch couplings. They differ mainly in the construction of the replacement part, more specifically in the shape of the fuselage and elastic insert. An example of such a solution is shown in Figure 10.

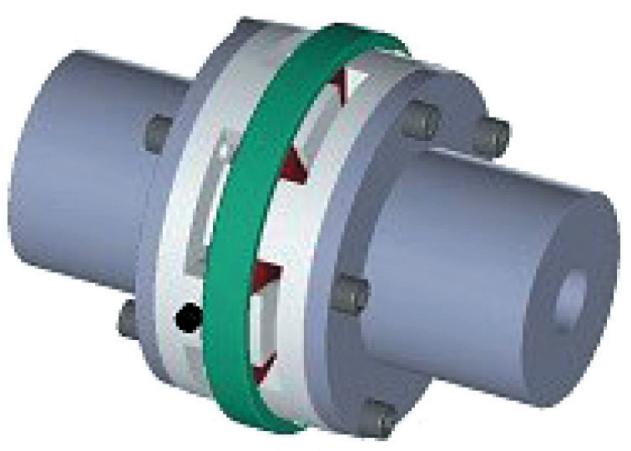

Fig. 10. Tschan BHDD-type coupling [10]

In conclusion, insert couplings are used in the drive systems of floor conveyors due to their low cost of production, durability, and lack of service during operation. They suppress the torsional vibrations; however, they have a relatively small relative angle of the twisting of the members and do not sufficiently support the start-up process of the conveyor. 
Tire couplings (Fig. 11) may also be used. They carry large torque and have a significantly higher susceptibility to the elastic than the inserts. Their additional advantage is the possibility of replacing the elastic pad without dismantling any of the components of the drive system.

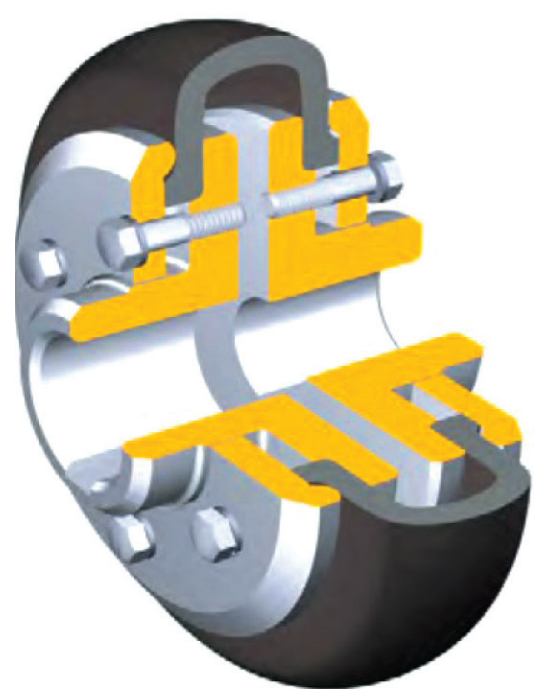

Fig. 11. Tire coupling [8]

A new type of clutch, which can find use in mining machinery drives in the near future, is the Dodge Raptor clutch. It combines the advantages of the high elasticity of a tire clutch and the easy replacement of the elastic cartridge with high durability and reliability. Figure 12 shows the Raptor clutch with fuses.

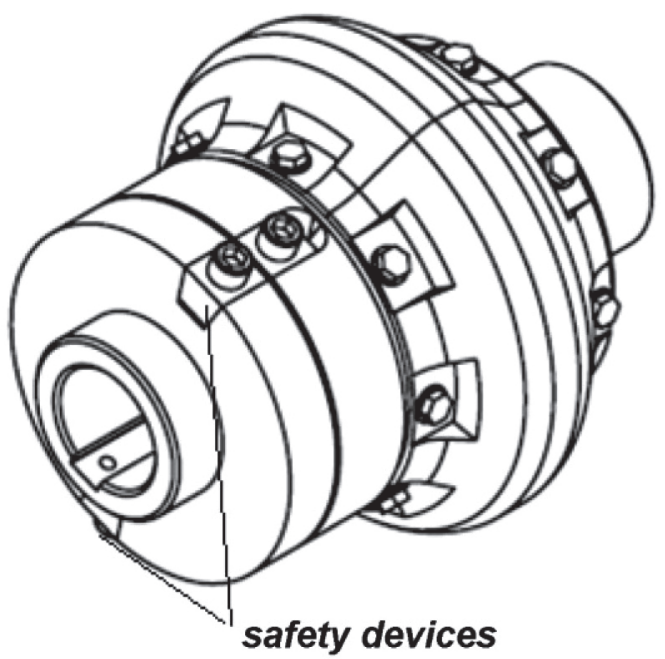

Fig. 12. Raptor-SK clutch with fuses [8]

The use of fuses in the coupling reduces the value of the transmitted torque to a value beyond which the chopping occurs; consequently, the drive will be disengaged.
The Raptor clutch coupling element consists of two parts. It is made of natural rubber and has a special design for high strength in sensitive areas. The toughness of this type of coupling is several dozen degrees higher than other clutches.

As mentioned earlier, elastic couplings have a number of drawbacks. First of all, they do not fully protect the components of the drive system from overload and do not meet expectations during the so-called heavy start-up, which can lead to the inability to start the conveyor without first unloading it. Therefore, hydrodynamic couplings have been widely used in the Polish mining industry.

Hydrodynamic couplings are a complex system in which the transfer of torque from the active member - the pump impeller to the passive member - is called a turbine impeller by means of a liquid connector [11-12]. There are mainly fixed couplings with or without retarder and flow [9].

For conveyors where heavy start-up is expected, the use of fixed-displacement torque couplings with a retard chamber is particularly applicable. The task of the extra chambers is to collect a portion of the fluid from the working chamber so that it is less dense. Ultimately, almost the unloading start of the conveyor motor is obtained. Voith Turbo $\mathrm{GmbH}$ with the coupling of the TV type is a potential producer of such couplings. The suppliers of this type of coupling on the Polish market are also companies such as Flender-Siemens with FV and FN clutches and (in the near future) Fasing (MOJ). Figure 13 shows the construction of one Voith 487 650 TVF series clutch. Voith couplings are built in several types, adapted to the specific working conditions of working machines. They differ mainly in their construction and size of their delay chambers.

Constant hydrodynamic couplings are protected by fuse plugs. Their purpose is to protect against the thermal overheating of the coupling and excessive pressure increase by releasing the working fluid.

Apart from hydrodynamic couplings with constant fluid filling in heavily loaded conveyors, clutches with an adjustable fill level of the working space are used. An example of such a clutch is shown in Figure 14 [13].

The initial start-up phase of the drive system with such a clutch is carried out without load (with the clutch disengaged). The hydraulic fluid is only supplied after the engine has been fully started, and the chain conveyor starts slowly from there. 


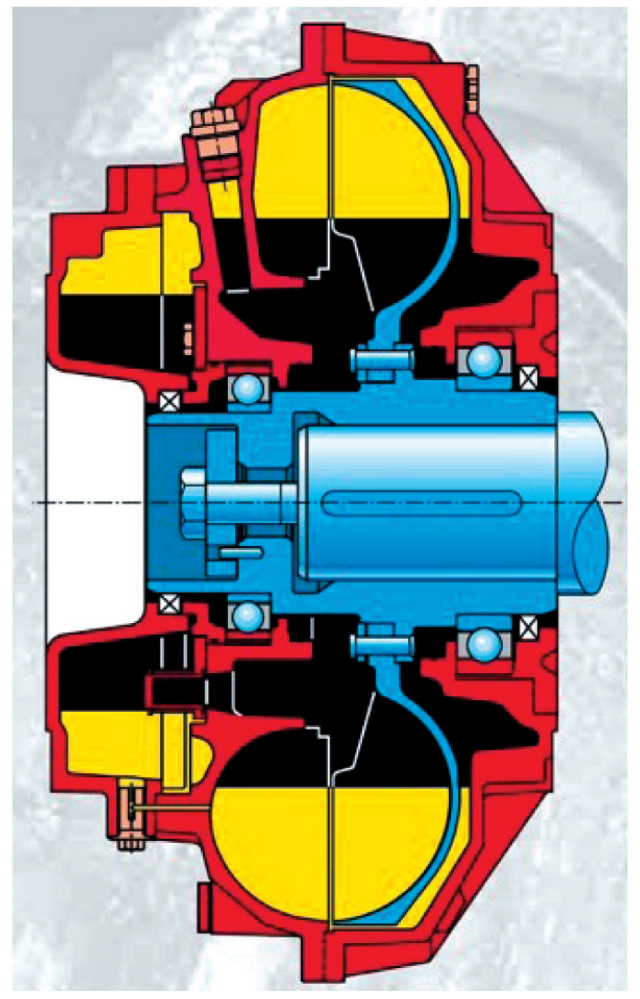

Fig. 13. Voith type 487650 TVF clutch [12]

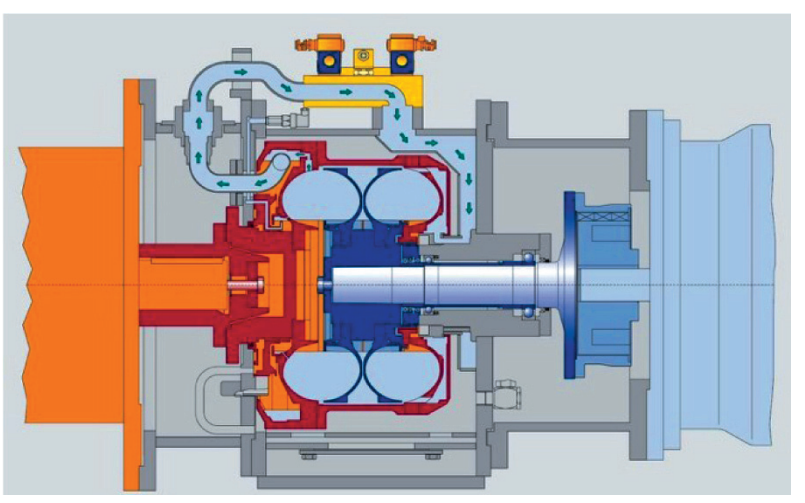

Fig. 14. Hydrodynamic coupler type DTPKWL 2 with adjustable water filling [13]

A wall-mounted floor conveyor equipped with adjustable-type hydrodynamic couplings moves into a steady state after reaching the working speed chain. The optimum size of the working space is $70 \%$ to $75 \%$ of the total capacity of the clutch when the conveyor is in operation [14].

When using this type of clutch, the working speed of the chain is reached about $30 \mathrm{~s}$ after startup, which is too long during times of frequent starts. This is a major disadvantage of this type of hydrodynamic coupling.

In the case of heavily loaded floor conveyors (where frequent couplings are expected), DTPW-type flow couplings [9] can be used. The design of this type of coupling was jointly developed by Voith and JOY. In this coupling, there is a continuous replacement of water coming most often from the fire pipe. Its volume in the clutch working chamber is constantly adjustable depending on the load condition of the conveyor. This clutch can work with approximately twice as much lubrication as a clutch with a constant filling.

In summary, hydrodynamic couplings are a common design that have been used in operational practice for several decades. They are characterized by a number of advantages, but their use is not devoid of disadvantages. This is why companies producing clutches for the mining industry sought new solutions.

The Halbach-Braun Company has proposed the construction of a multi-plate overload clutch (slip clutch). They can be installed between the motor and gearbox as well as at the transmission shaft of the transmission.

This type of clutch is located between the motor and the gear unit in series with a flexible coupling; e.g., insert. However, these clusters are very rare in the national mining industry [9].

Voith is also used in its SafeSet overload clutch (Fig. 15). They are used primarily in the mining conveyors of the American mining machinery manufacturer Joy Mining Machinery. In this case, there is also a slip in the clutch mechanism. Adjustment of the torque in takes place in its hydraulic system.

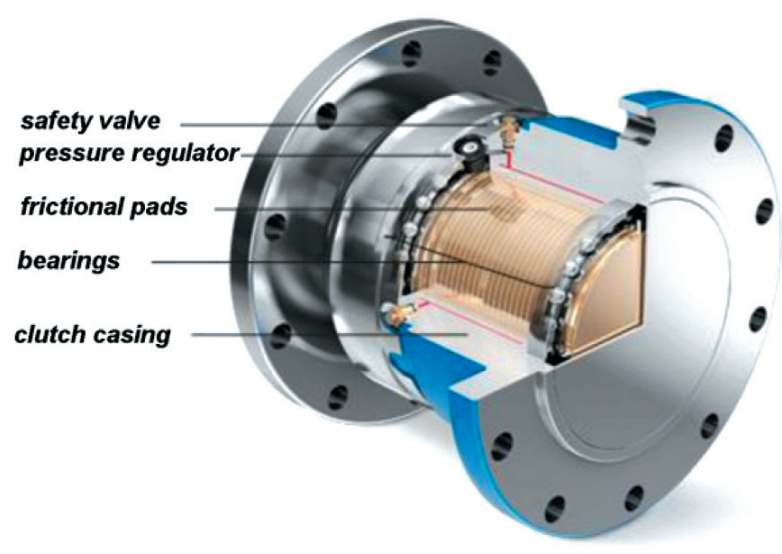

Fig. 15. Construction of Voith SafeSet overload clutch [15]

The Safesydor systems from Dorstener and the DBS from DBT and Dodge are used for a more-advanced ways of securing the drive systems from overload, difficult starting, and leveling of individual 
drives in the wall conveyor. In both cases, the safety components were directly linked to the gear unit.

In the first of these solutions, the planetary gear wheel of the first planetary stage was associated with a oil lubricated multi-plate clutch (Fig. 16).

This solution allows for both the easy startup of the conveyor and also protecting the drive system from overload during a fixed operation. In addition, it allows us to balance the power of the individual motors.

However, this system has not found much use in mining practice [9]. The disadvantages of this system are the high cost of production associated with a complex control system as well as the poor co-operation with two-speed motors.

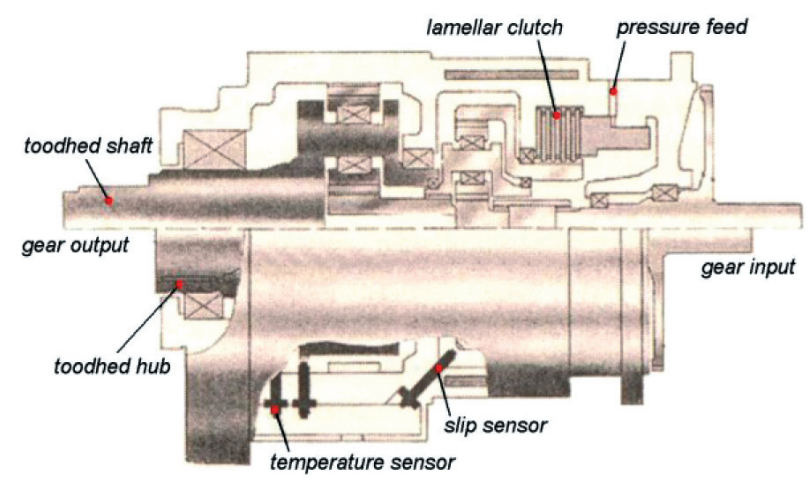

Fig. 16. Dorstener Safesydor system [9]

For floor conveyor drives, the CST (Control Start Transmission) system has been used since the mid-1990s. Contrary to the name, this solution is not only intended to facilitate the start-up of the conveyor, but through the control system and associated sensor systems, it is able to react to any load changes in the conveyor.

As with the Safesydor system, the CST drive system integrates two drive system components: the gearbox and clutch. They are placed in two interconnected permanent parts of the common enclosure. In one part, there is a planetary gearbox with a builtin CST clutch mounted on the output shaft. This is a wet multi-plate clutch with special ceramic linings (Fig. 17).

The other parts of the system (gray in Fig. 16) contain other components of the system, such as:

- high pressure pump, oil heat exchanger;

- hydraulic control, precision servo valve with smooth adjustment;

- pressure, temperature, and input/output speed sensor;

- electronic pre-treatment of measured values;

- PROTEC drive controller.

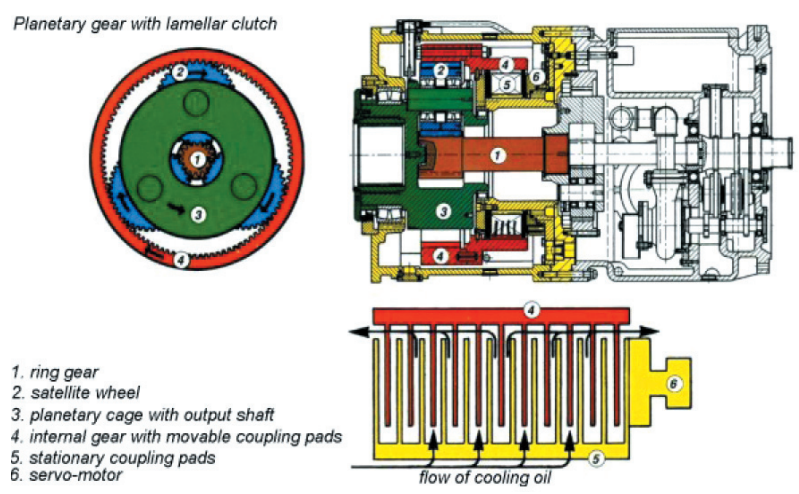

Fig. 17. Integrated CST system [16]

In the start-up phase, all motors of the floor conveyor are started. This is done without load. Only when the CST system is fully engaged is the oil supplied to the CST system. During this run-in phase, the oil pressure increases; therefore, the load on the motor is synchronized. When there is a difference in power consumption in the less-loaded drive, the pressure is increased, as a result of which the clutch disc clutches increase and the slip is reduced until the load is equalized. Conversely, if the conveyor drive is blocked, the device driver instructs the relevant actuators to completely disconnect all of the drives.

Apart from the undoubted advantages of the CST system, there are also disadvantages that make it rare in the Polish mining industry. This solution is characterized by a quite-complicated construction, which affects the price of its production and maintenance costs [17]. There, there is also a high demand for the technical culture of its use [9]. These negative features have made this solution much less common compared to hydrodynamic couplings.

The clutch constructions used in mining floor conveyors have been characterized by numerous advantages and disadvantages. Older designs are characterized by their simplicity, low production, and low operating costs; however, they do not meet the expectations that they face. Newer couplings meet these expectations, but they are distinguished by the increasing complexity of construction (which increases their production and service costs). Therefore, new construction solutions for couplings should be sought. For example, one such solution is the construction of the metal torsionally flexible coupling that has been developed at the Department of Mining Robotization and Mechanization of the Faculty 
of Mining and Geology at the Silesian University of Technology.

This component is made entirely of metal, which is a significant difference compared to the currently produced construction. Its idea, structure, and principle of operation have been described in the following references [18-20]. It is characterized by simplicity of construction and (consequently) its low cost of production.

Figure 18 shows a clutch view designed for a $400 \mathrm{~kW}$ electric motor. It is integrated with an insertion clutch that is located between the motor and the gear unit.

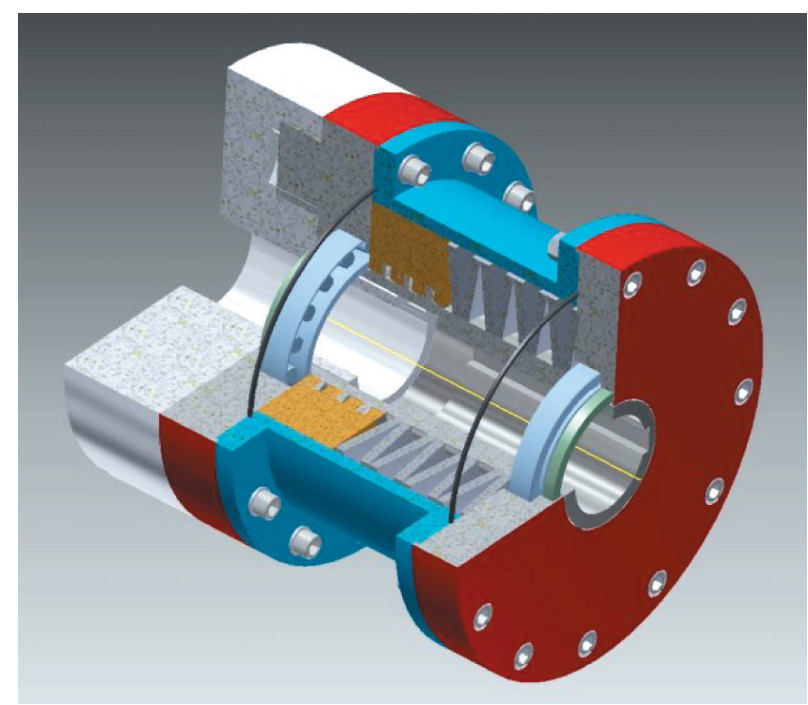

Fig. 18. View of solid metal clutch model designed for 400-kW floor conveyor drive system

The torsionally flexible metal clutch mechanism can also be located in the drive drum (Fig. 19). Integrating the two drive system components into one drive saves space. This is an original solution that has not been used thus far.

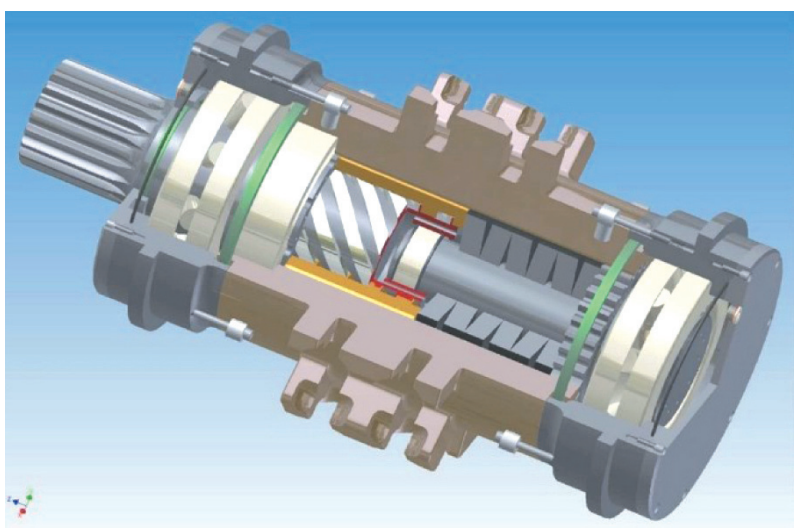

Fig. 19. Torsionally flexible metal coupling with drum drive of floor conveyor (power: $400 \mathrm{~kW}$ )
The overload protection of the drivetrain is also ensured by a proper chain coil chaining. This problem was solved at the Department of Mining Robotization and Mechanization of the Faculty of Mining and Geology at the Silesian University of Technology. Movement and vibration caused by the movement of the spoil in the gutters cause an elongation in the chain. The consequence of this phenomenon is a disturbance in the conveyor operation caused by the improper co-operation of the drum with the chain at the point of its descent. The solution to this problem is to apply the correct adjustment of the required chain tension to the operating conditions of the conveyor. This is done by shifting the auxiliary drive hull using a suitable control algorithm called ASTEN [21].

\subsection{Belt conveyors}

Belt conveyors are the next link in the conveyor system from the longwall.

In the conveyor belt drive system, the following technical solutions are used as overload protection (which occurs mainly during start-up) [22]:

- two-speed motors,

- thyristor starters,

- frequency inverters,

- use of DC motor,

- flexible couplings,

- hydrodynamic coupling,

- CST system.

As with scraper conveyor systems, the start-up of the conveyor belt is accomplished by using the appropriate starting devices. These units support the start-up phase of the conveyor by electrical or mechanical means.

The mechanical start-up assistance is carried out through a clutch mechanism. The simplest solution is to use a flexible clutch, but this solution is not suitable for long and overly inertial conveyors. The low torsional rigidity of such a coupling reduces the loading capacity of the loaded conveyor.

Belt conveyors also use hydrodynamic couplings, most often with constant filling. These are Voith system couplings T, TV, TVV, and TVVS [22]. Flow couplers with the adjustable filling of the TPKL system (Fig. 20) and DTPKL or their variants may also be used [22]. 


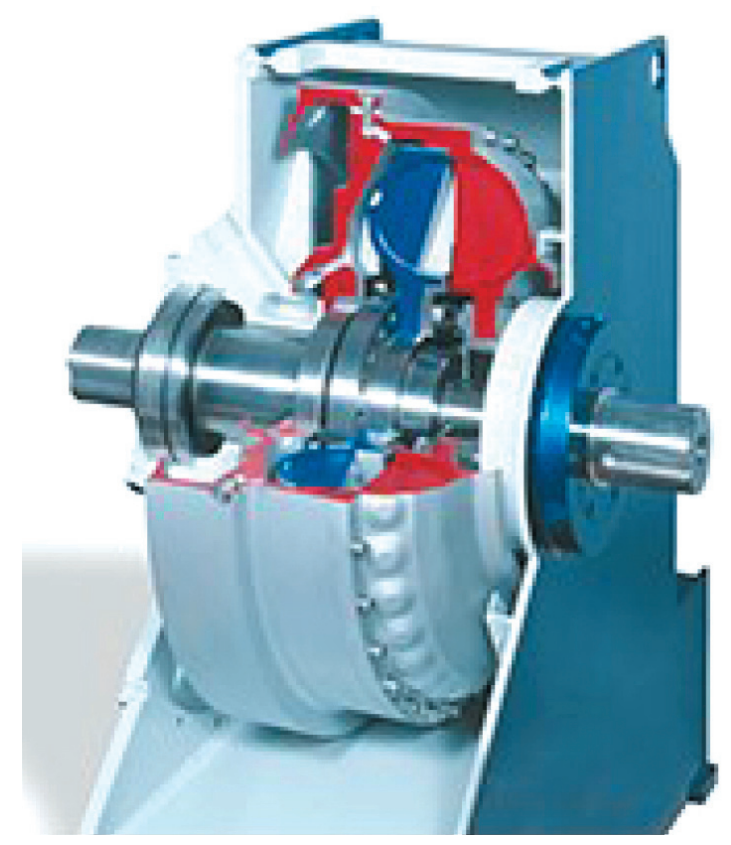

Fig. 20. Voith's TPKL flow clutch [15]

The CST artificial intelligence systems [22] described above are used for the startup of multistage tape conveyors of considerable length and inertia. This system is well-suited to work with the same type of drive in a conveyor equipped with drum intermediate drives, where the correct positioning of a drive with identical engine power is very difficult.

\section{SUMMARY}

Machines used in underground mining work under particularly difficult working and environmental conditions. This applies to the excavating and transporting machines in particular. In addition, modern mining saddles them with particularly difficult requirements, because they are characterized by high reliability and significant durability. Their failurefree operation depends on the continuity of mining in the mining plant.

The continuous increase in the efficiency of technological processes in underground mining (i.e., the efficiency of machines entering the mining cycle) makes the drive system most vulnerable to dynamically changing loads during operation, which is the most-important component of each mining machine. Its effectiveness depends on the efficiency of the machine.
In order to mitigate these unfavorable operating conditions in mining excavations, indirect and direct methods can be used to prevent overload occurring during the start-up phase and fixed work.

Indirect methods are related to the control system, where the engine parameters are controlled without blocking or overheating.

In direct methods, clutches of different construction are used. Cartridge couplings consist of durable components and have a simple construction and operating principle, but they have a lot of limitations. More-advanced systems such as CST, Safesydor, and popular hydrodynamic couplings have many advantages, but they no are also free of defects. This is why we are constantly looking for new solutions. One of them may be a metal torsionally flexible coupling which has been developed in the Department of Mining Robotization and Mechanization of the Faculty of Mining and Geology at the Silesian University of Technology. It has a much-higher torsional rigidity compared to the insert clutch couplings combining the simplicity of construction with them.

\section{References}

[1] Broen A.: Kombajny chodnikowe, Wydawnictwo Śląsk, Katowice 1980.

[2] Dolipski D., Cheluszka P.: Dynamika układu urabiania kombajnu chodnikowego, Wydawnictwo Politechniki Śląskiej, Gliwice 2002.

[3] Świtoński E., Chuchnowski W.: Optymalizacja cech konstrukcyjnych mechatronicznych układów napędowych maszyn górniczych, "Maszyny Górnicze" 2008, 4: 23-30.

[4] Rupik J., Skrzypie A., Kurek M.: Doświadczenia eksploatacyjne napędów maszyn przeznaczonych dla górnictwa od hydraulicznych do elektrycznych, "IV Szkoła Mechanizacji i Automatyzacji Górnictwa”, Szczyrk 2008.

[5] Suchoszek J., Nogas Z.: Współpraca DAMEL-u z ZZM S. A., Sympozjum z okazji 60-lecia Zabrzańskich Zakładów Mechanicznych S. A., Zabrze 2007.

[6] Grzesica P.: Wpływ obciązenia zewnętrznego na sity międzyzębne $w$ przekładniach zębatych maszyn górniczych, Wydawnictwo Politechniki Śląskiej, Gliwice 2011.

[7] Sprzegła elastyczne typu SP, Technical and operational documentation, MOJ S.A. (Grupa Fasing), Katowice 2013.

[8] Offer of Fabryka Elementów Napędowych FENA, Katowice 2017.

[9] Suchoń J.: Górnicze przenośniki zgrzebłowe. Budowa i zastosowanie, Instytut Techniki Górniczej KOMAG, Gliwice 2012.

[10] Offer of TZ Polska Sp. z o.o., Bytom.

[11] Antoniak J.: Przeptywowe sprzęgła wodne do napędów wysokowydajnych ścianowych przenośników zgrzebłowych, "Mechanizacja i Automatyzacja Górnictwa" 2002, 11: 21-29.

[12] Start-up Components for Mining - advertising brochure of Voith Turbo GmbH \& Co. KG, Crailsheim 2007.

[13] Fill-controlled Fluid Couplings - advertising brochure of Voith Turbo GmbH \& Co. KG, Crailsheim 2007. 
[14] Antoniak J.: Urzadzenia i systemy transportu podziemnego w kopalniach, Wydawnictwo Śląsk, Katowice 1990.

[15] Offer of Voith GmbH \& Co, Niemcy 2017.

[16] Zintegrowany uktad napędowy WB/CST - advertising brochure of DBT GmbH, Lünen 2000.

[17] Mendyka P.: Układy rozruchowe ścianowych przenośników zgrzebtowych, "Napędy i Sterowanie" 2014, 7/8: 138-144.

[18] Filipowicz K.: Doświadczalna i teoretyczna identyfikacja cech dynamicznych nowej konstrukcji sprzegła podatnego w zastosowaniu do układu napędowego maszyn górniczych, Wydawnictwo Politechniki Śląskiej, Gliwice 2009.

[19] Filipowicz K., Kuczaj M.: Wpływ metalowego sprzęła podatnego skrętnie na pracę układu napędowego przenośnika zgrzebłowego, XXIII Międzynarodowa Konferencja Naukowo-Techniczna "Trwałość Elementów i Węzłów Konstrukcyjnych Maszyn Górniczych TEMAG” 2015: 19-30.

[20] Kuczaj M., Filipowicz K.: Badania symulacyjne wptywu metalowego sprzęła podatnego skrętnie na rozruch uktadu napędowego, XXIII Międzynarodowa Konferencja Naukowo-Techniczna "Trwałość Elementów i Węzłów Konstrukcyjnych Maszyn Górniczych TEMAG” 2015: 89-98.

[21] Dolipski M., Cheluszka P., Remiorz E., Sobota P.: Innowacyjne górnicze przenośniki zgrzebłowe, Wydawnictwo Politechniki Śląskiej, Gliwice 2017.

[22] Antoniak J.: Przenośniki taśmowe: wprowadzenie do teorii i obliczenia, Wydawnictwo Politechniki Śląskiej, Gliwice 2004.
KRZYSZTOF FILIPOWICZ, D.Sc., Eng. MARIUSZ KUCZAJ, Ph.D., Eng. MACIEJ KWAŚNY, Ph.D., Eng.

Department of Mining Mechanization and Robotization

Faculty of Mining and Geology Silesian University of Technology ul. Akademicka 2, 44-100 Gliwice, Poland $\{k r z y s z t o f$ filipowicz, mariusz.kuczaj, maciej.kwasny\}@polsl.pl

KRZYSZTOF TWARDOCH, Ph.D., Eng. Institute of Machine Design Fundamentals Faculty of Automotive and Construction Machinery Engineering

Warsaw University of Technology ul. Narbutta 84, 02-524 Warsaw, Poland krzysztof.twardoch@simr.pw.edu.pl 


\title{
Bezpieczeństwo układów napędowych maszyn górniczych - zagadnienia wybrane
}

\begin{abstract}
Wspótczesne maszyny stosowane $w$ górnictwie podziemnym pracuja $w$ skrajnie trudnych warunkach środowiskowych, zwłaszcza przy zmiennym obciażeniu. Jest to powodem występowania obciażeń dynamicznych, które w szczególności oddziałuja na zespoły mechaniczne układu napędowego maszyny, wptywając niekorzystnie na jego trwałość, niezawodność oraz bezpieczeństwo użytkowania. Przeciwdziałanie występującym niekorzystnym skutkom wzajemnych oddziatywań dynamicznych elementów układów napędowych jest możliwe $w$ wyniku stosowania odpowiednich metod i środków prowadzacych do ograniczenia tych obciążen. Specyfika pracy maszyn górniczych sprawia, że szczególnie duże obciażenia dynamiczne $z$ licznymi stanami przeciażenia występuja zarówno podczas rozruchu, jak i pracy ustalonej. $W$ artykule przedstawiono stosowane aktualnie metody tagodzenia skutków obciażen dynamicznych podczas rozruchu i zabezpieczania uktadów napędowych, które może odbywać się w sposób elektryczny lub mechaniczny. Zaprezentowano również wybrane konstrukcje sprzegiet stosowanych w maszynach górniczych mających za zadanie tagodzenie obciązeń dynamicznych $i$ zabezpieczanie napędów podczas ich pracy ustalonej.
\end{abstract}

Słowa kluczowe: zabezpieczenie, przeciązenie, układ napędowy

\section{WPROWADZENIE}

Podstawowymi maszynami ze względu na proces wydobywczy, zainstalowanymi w podziemnych kopalniach węgla kamiennego są maszyny urabiające i przeznaczone do odstawy urobku z przodka ścianowego. Należą one do grupy maszyn najbardziej narażonych na oddziaływania eksploatacyjne w górnictwie podziemnym. Sytuacja ta wymaga zwrócenia szczególnej uwagi na proces ich projektowania, a później eksploatacji.

Podstawowym zespołem mechanicznym pośredniczącym w wykonywaniu pracy użytecznej każdej maszyny górniczej jest jego układ napędowy. W jego skład zwykle wchodzą takie elementy, jak: silnik elektryczny, przekładnia (zębata), sprzęgła oraz element lub elementy wykonawcze, najczęściej w postaci organu urabiającego czy bębna napędowego.

Główne zespoły mechaniczne w układzie napędowym maszyn urabiających i odstawczych, tj. sprzęgła i przekładnie zębate, narażone są na szczególnie intensywne wymuszenia eksploatacyjne $\mathrm{w}$ postaci zmiennych obciążeń ze znacznymi chwilowymi przeciążeniami o dużej częstotliwości, które występują przede wszystkim w nieustalonych stanach rozruchowych (przenośniki zgrzebłowe), a także podczas pracy ustalonej. Ostatecznym skutkiem tych oddziaływań jest zmniejszenie ich niezawodności, a ostatecznie trwałości. Sposobem zaradczym na niekorzystne warunki eksploatacyjne jest zastosowanie specjalnych środków technicznych mających na celu zabezpieczenie elementów układu napędowego przed przeciążeniem. Przykładem może być układ napędowy przenośnika zgrzebłowego, gdzie znaczne problemy sprawia już sam jego rozruch. Zastosowanie mają tutaj urządzenia rozruchowe ułatwiające ten proces na drodze elektrycznej lub/oraz mechanicznej. Tak jak wspomniano, przeciążenia występują również podczas pracy ustalonej maszyny (kombajn chodnikowy, ścianowy, przenośniki ścianowe i podścianowe). W tym przypadku zastosowanie mają przede wszystkim sprzęgła podatne skrętnie o różnej konstrukcji. 
W niniejszym artykule zarazem w sposób przeglądowy, jak i syntetyczny ujęto problematykę zabezpieczenia układów napędowych wybranych maszyn górniczych przed niekorzystnym działaniem warunków eksploatacyjnych. Skupiono się przede wszystkim na stosowanych rozwiązaniach mechanicznych.

\section{ZABEZPIECZENIE UKŁADU NAPĘDOWEGO MASZYN URABIAJACCYCH}

W procesie wydobycia węgla kamiennego jako maszyny do urabiania urobku są wykorzystywane kombajny ścianowe oraz chodnikowe.

Kombajny chodnikowe służą do drążenia wyrobisk korytarzowych udostępniających, a także wydobywania węgla kamiennego, soli oraz rud miedzi. Poszczególne ruchy robocze elementów wykonawczych są realizowane za pomocą układów napędowych organu urabiającego, podwozia gąsienicowego oraz ładowarki urobku.

Najbardziej obciążony jest układ napędowy głowic urabiających. Co prawda, ich rozruch odbywa się przeważnie bez obciążenia, lecz występują z kolei duże obciążenia dynamiczne pochodzące od skrawania nożami calizny węglowej lub kamiennej. Niestałość parametrów mechanicznych urabianej calizny oraz sposób przemieszczania głowic urabiających przez operatora są powodem występowania zmiennego obciążenia w układzie przeniesienia napędu z silnika elektrycznego do głowic urabiających. Na rysunku 1 przedstawiono jako przykład budowę organu urabiającego kombajnu chodnikowego AM-50z. W zależności od rozwiązania konstrukcyjnego w danym modelu kombajnu reduktor może przybierać różną postać pod względem kinematycznym, jednak łącznikiem pomiędzy wałem wejściowym reduktora a silnikiem jest zawsze sprzęgło podatne. W większości przypadków jest to sprzęgło wkładkowe bądź, tak jak w przypadku kombajnu AM 50z, sprzęgło palcowe.

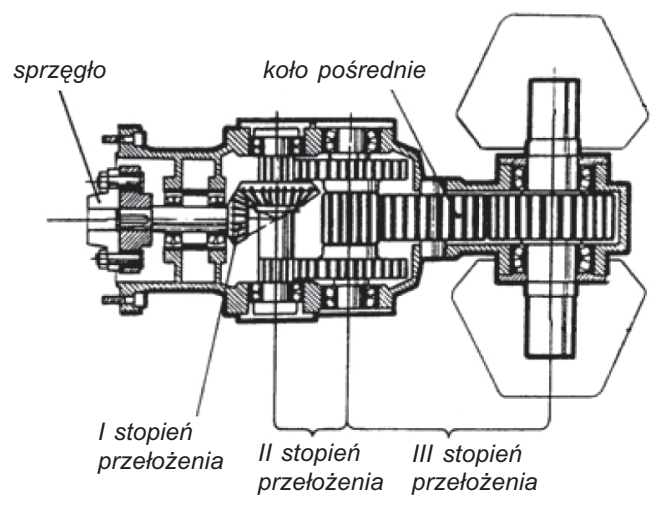

Rys. 1. Uktad napędowy głowicy urabiajacej kombajnu chodnikowego AM-50z [1]
Sprzęgło to ma za zadanie w pierwszej kolejności złagodzić obciążenie dynamiczne pojawiające się na wale wejściowym przekładni od silnika podczas jego rozruchu, a następnie łagodzić obciążenie na wale silnika pochodzące od reakcji na obciążenie skrawaniem. Na rysunku 2 przedstawiono człon bierny sprzęgła wkładkowego, a na rysunku 3 sprzęgła palcowego podłużnej głowicy urabiającej.

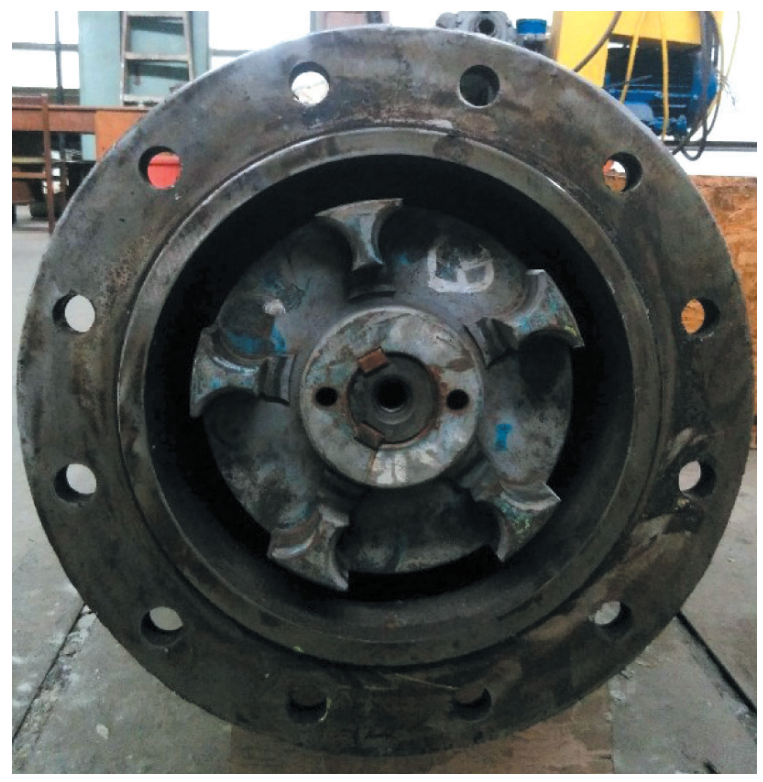

Rys. 2. Widok cztonu biernego sprzęła wktadkowego zastosowanego $w$ organie urabiajacym kombajnu chodnikowego

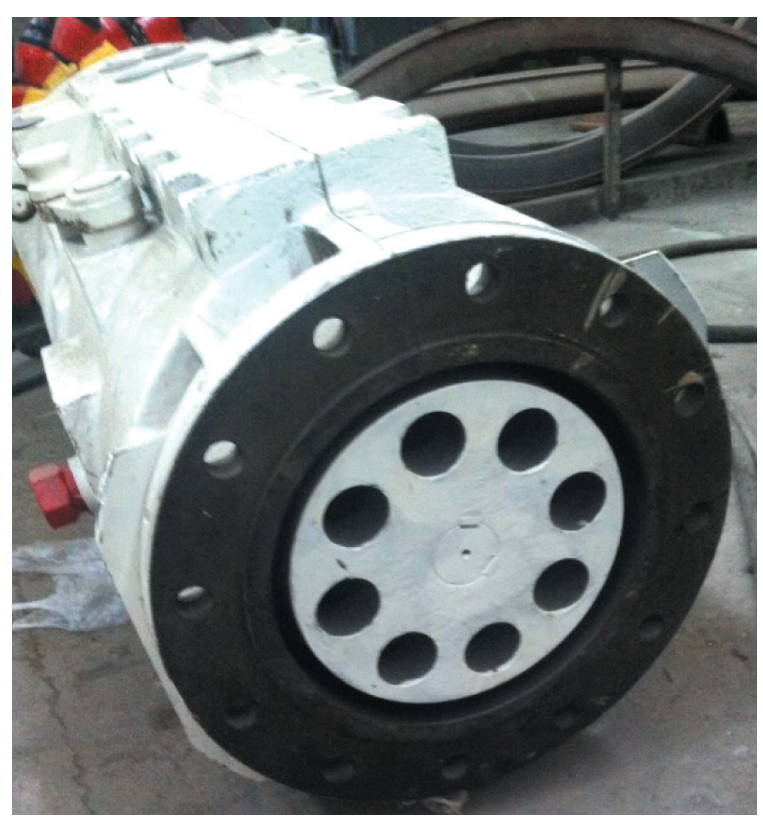

Rys. 3. Widok członu biernego sprzegła palcowego zastosowanego $w$ organie urabiajacym kombajnu chodnikowego 
Oprócz sprzęgieł podatnych mogą być stosowane również sprzęgła cierne, tak jak ma to miejsce np. w kombajnie AM-75. Pełni ono też wtedy funkcję sprzęgła przeciążeniowego.

Zabezpieczeniem przeciążeniowym w organie urabiającym jest przede wszystkim pierścień rozporowy (rys. 4), za pomocą którego przenoszony jest moment obrotowy z wału biernego reduktora na głowicę urabiającą.

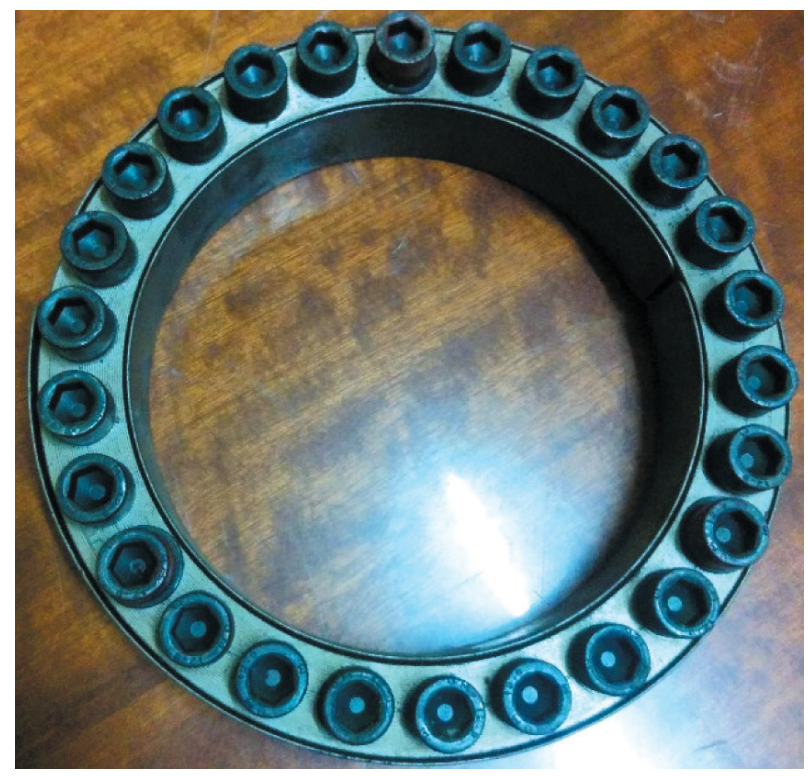

Rys. 4. Widok pierścienia rozporowego do zastosowania w głowicy urabiającej kombajnu

Stanowi on połączenie cylindrycznej gładkiej piasty głowicy urabiającej z cylindrycznym gładkim walcem wyjściowym reduktora [2]. Podczas wystąpienia przeciążenia dochodzi do przekroczenia wartości momentu sił tarcia w pierścieniu, występuje wtedy poślizg i przerwa w przekazaniu momentu na głowicę urabiającą.

Oprócz bezpośrednich metod zabezpieczenia ukła$\mathrm{du}$ napędowego urabiania $\mathrm{w}$ kombajnie chodnikowym przed przeciążeniem stosowane są metody pośrednie, do których zalicza się [2]:

- zabezpieczenie termiczne silnika napędowego,

- ograniczenie siły docisku głowicy urabiającej do calizny w miarę wzrostu ciśnienia w układzie zasilania siłowników wychylania wysięgnika,

- ograniczenie prędkości przemieszczania głowicy urabiającej w miarę wzrostu poboru mocy przez silnik w układzie urabiania.

Kolejną maszyną wykorzystywaną do równoczesnego urabiania i ładowania urobku na przenośnik jest kombajn ścianowy. Wchodzi on w skład kompleksu ścianowego. Na rysunku 5 przedstawiono przykładowy widok modelu geometrycznego układu napędowego organu urabiającego.

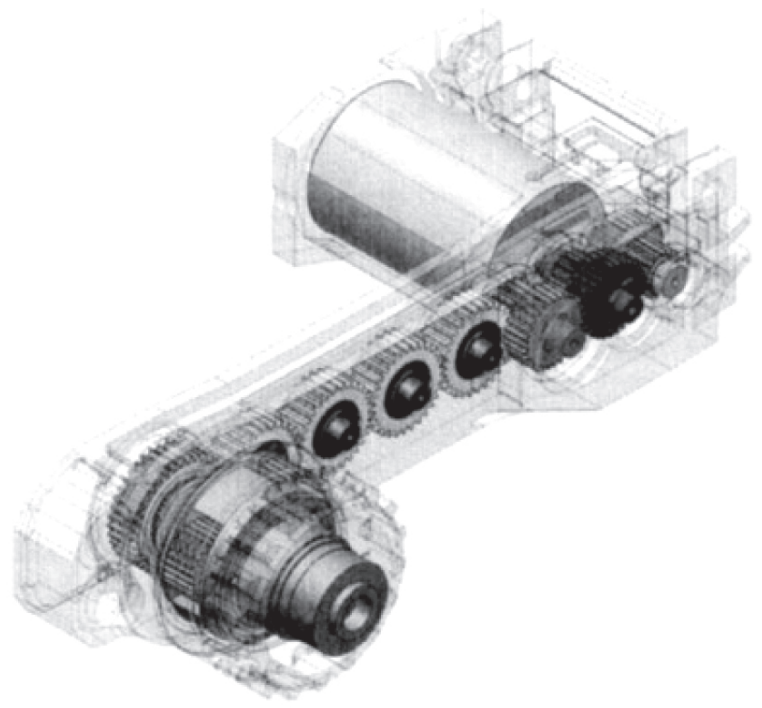

Rys. 5. Model geometryczny uktadu napędowego kombajnu ścianowego [3]

Zabezpieczenie układu napędowego przed przeciążeniem wynikającym z procesu urabiania calizny węglowej może odbywać się bezpośrednio lub pośrednio. Do pośrednich metod należą wszelkie zabezpieczenia ujęte $\mathrm{w}$ systemie sterowania kombajnu, np. układ sterowania Faceboss marki Joy, gdzie kontrolowane są parametry silników, aby nie dopuścić do ich zablokowania i przegrzania.

Największe obciążenia od urabiania calizny węglowej występują w układzie napędowym organu urabiającego. Co prawda, sam proces rozruchu nie stanowi problemu, gdyż odbywa się bez obciążenia, jednak podczas procesu skrawania dochodzi do występowania obciążeń o dużej zmienności w czasie, a jego intensywność jest uzależniona od prędkości posuwu kombajnu.

Zabezpieczenie podzespołów układu napędowego organu urabiającego oraz napędu posuwu przed przeciążeniem mogą stanowić wały bezpiecznikowe przekazujące moment obrotowy silnika na pierwszy stopień przekładni $[4,5]$. Rozwiązanie to ma zastosowanie np. w kombajnach KSW 460, KSW 620E oraz KSW-1140E. Wał bezpiecznikowy ma wykonane podcięcie i w przypadku wystąpienia przeciążenia w układzie napędowym w tym miejscu dochodzi do jego zniszczenia. Wał ten jest w prosty sposób wymieniany na nowy od strony zawałowej. 


\section{ZABEZPIECZENIE UKŁADU NAPĘDOWEGO MASZYN TRANSPORTUJACYCH UROBEK}

\subsection{Przenośniki zgrzebłowe}

Przenośniki zgrzebłowe ścianowe i podścianowe stanowią początek ciągu transportującego urobek z przodka ścianowego. Warunki pracy przenośnika zgrzebłowego ścianowego należą do najcięższych warunków eksploatacyjnych w górnictwie podziemnym. Znaczne problemy sprawia już bowiem rozruch maszyny spowodowany głównie masą urobku znajdującego się na trasie, a także zbyt duże napięcie wstępne łańcucha oraz wszelkie problemy po stronie zasilania silników (stan sieci kopalnianej, niewłaściwa kolejność załączania napędów itp.).

Oprócz utrudnionego rozruchu główne mechanizmy układu napędowego ścianowego przenośnika zgrzebłowego są narażone na szczególnie intensywne wymuszenia eksploatacyjne $\mathrm{w}$ postaci zmiennych obciążeń ze znacznymi chwilowymi przeciążeniami, również podczas pracy ustalonej.

Przeciwdziałanie występującym niekorzystnym skutkom wzajemnych oddziaływań elementów układów napędowych przenośników zgrzebłowych możliwe jest w wyniku stosowania odpowiednich metod i środków prowadzących do ograniczenia przenoszonych obciążeń dynamicznych, gdyż mają one znaczący wpływ na rozwój procesów degradacyjnych, a zwłaszcza zmęczeniowych.

Tak jak wspomniano, duży problem stanowi rozruch załadownego przenośnika. Jest to szczególnie istotne, gdyż praktyka kopalniana pokazuje, że przenośnik ścianowy jest stosunkowo często włączany i wyłączany [6].

Umożliwienie rozruchu załadowanego przenośnika jest możliwe po przedsięwzięciu odpowiednich środków technicznych. Może ono odbywać się metodą elektryczną (najprostszym rozwiązaniem jest zastosowanie silnika dwubiegowego) lub mechaniczną. Stosowanymi urządzeniami rozruchowymi przy metodzie elektrycznej są:

- rozruszniki stycznikowe,

- agregaty tyrystorowe,

- przemienniki częstotliwości.

Umożliwienie rozruchu przenośnika, a także ograniczenie negatywnych skutków wzajemnych oddziaływań elementów układu napędowego podczas pracy ustalonej jest możliwe również przez zastosowanie prostych sprzęgieł podatnych skrętnie oraz bardziej zaawansowanych konstrukcyjnie sprzęgieł przeciążeniowych/rozruchowych.

Aktualnie w górniczych przenośnikach zgrzebłowych często są stosowane na wejściu układów napędowych, między silnikiem i przekładnią, sprzęgła elastyczne z wkładkami elastomerowymi lub poliuretanowymi jedno- (rys. 6) lub dwuwkładkowe (rys. 7).

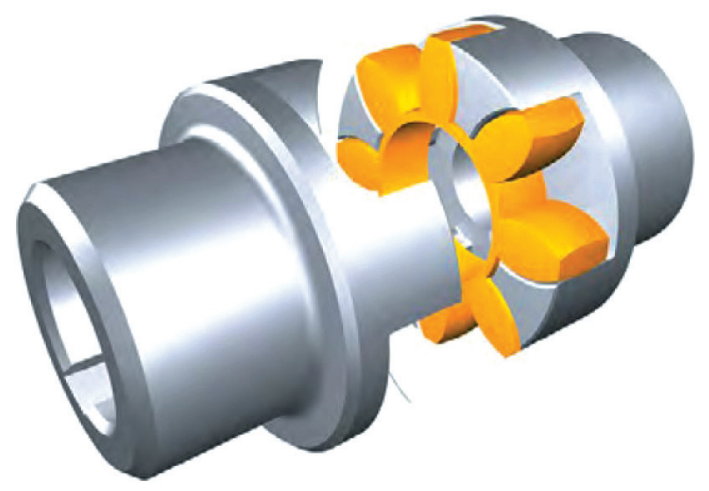

Rys. 6. Sprzęto podatne jednowktadkowe $S P(A S R)[7,8]$

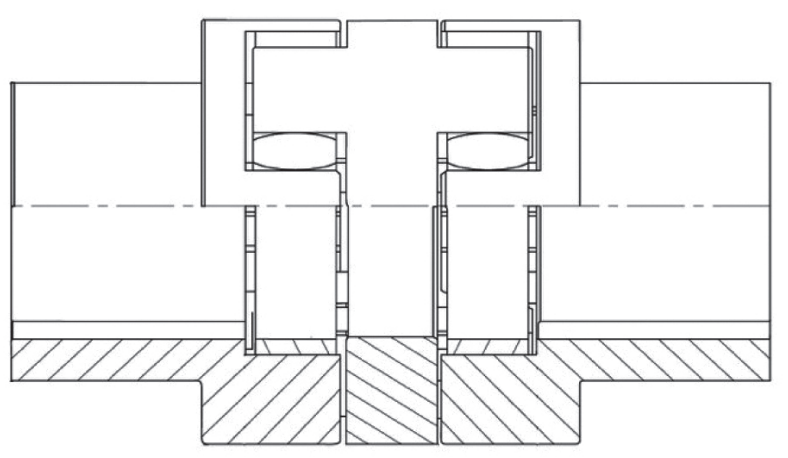

Rys. 7. Sprzęło podatne dwuwktadkowe $S P P(A S R)[7]$

W przenośnikach zgrzebłowych wykorzystywane jest również połączenie sprzęgła podatnego z przeciążeniowym. Na rysunku 8 przedstawiono przykładową konstrukcję takiego rozwiązania.

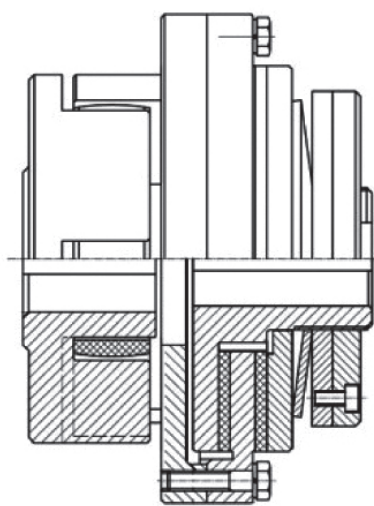

Rys. 8. Sprzegło przeciażeniowe APMX [8] 
Jest to typowe sprzęgło wkładkowe $\mathrm{z}$ regulowaną wartością momentu obrotowego, przy którym następuje poślizg na okładzinach ciernych i dochodzi do rozłączenia napędu.

Stosowane są również inne konstrukcje sprzęgieł podatnych. Przykładem może być sprzęgło, którego producentem jest RFM Ryfama (rys. 9), gdzie elementem elastycznym jest gumowy torus, w którym są zawulkanizowane tulejki stalowe. W tulejki wchodzą naprzemiennie stalowe trzpienie mocowane do tarcz znajdujących się na członie czynnym i biernym sprzęgła [9].

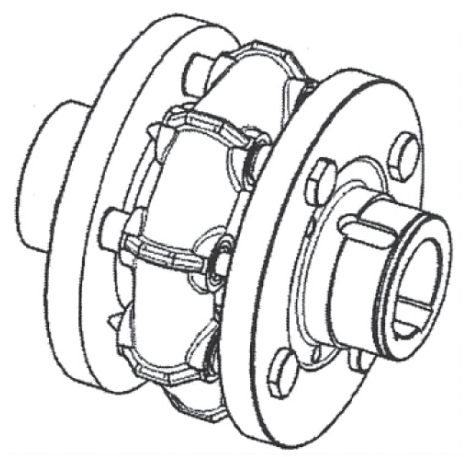

Rys. 9. Sprzegto podatne produkcji RFM Ryfama [9]

Z kolei oryginalne rozwiązanie sprzęgła podatnego o wymiennej części elastycznej (wkładki) bez demontażu silnika ma w swojej ofercie firma TZ Polska. Są to sprzęgła kłowe typu BHDD i SDD. Różnią się one głównie konstrukcją części wymiennej, a dokładniej ujmując: kształtem kłów i wkładki elastycznej. Przykład takiego rozwiązania przedstawia rysunek 10.

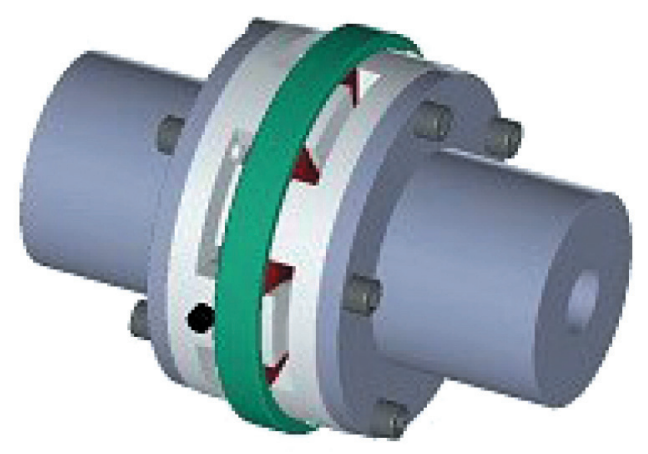

Rys. 10. Sprzegło typu Tschan BHDD [10]

Podsumowując, sprzęgła wkładkowe ze względu na swe atuty, jakimi są niski koszt wytwarzania, trwałość oraz brak obsługi podczas eksploatacji, wykorzystywane są w układach napędowych przenośników zgrzebłowych. Tłumią one drgania skrętne, jednak posiadają stosunkowo mały względny kąt skręcenia członów i nie wspomagają w wystarczający sposób procesu rozruchu przenośnika.
W napędach przenośników zgrzebłowych mogą mieć zastosowanie również sprzęgła oponowe (rys. 11). Przenoszą one duże momenty obrotowe i posiadają wyraźnie większą podatność elementu elastycznego w porównaniu ze sprzęgłami wkładkowymi. Dodatkowym ich atutem jest możliwość wymiany wkładki elastycznej bez demontażu któregoś z elementów układu napędowego.

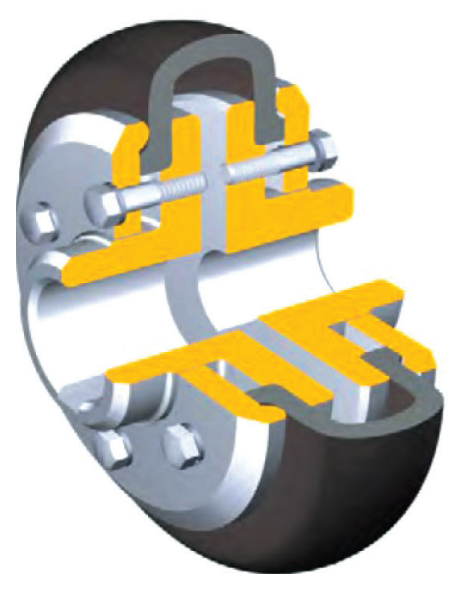

Rys. 11. Sprzegło oponowe [8]

Nowym typem sprzęgła, które w najbliższej przyszłości może znaleźć zastosowanie w napędach maszyn górniczych, jest sprzęgło Raptor firmy Dodge. Łączy ono w sobie zalety wysokiej elastyczności sprzęgła oponowego i łatwej wymiany wkładu elastycznego $\mathrm{z}$ wysoką żywotnością i niezawodnością. Na rysunku 12 przedstawiono widok sprzęgła Raptor w wersji z bezpiecznikami.

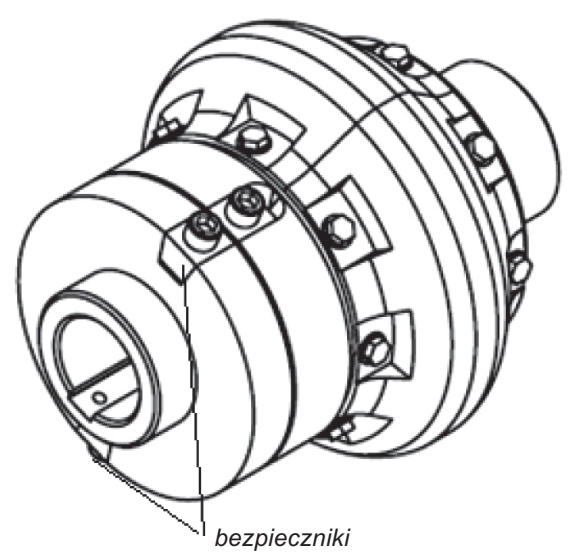

Rys. 12. Sprzegło podatne Raptor-SK
z bezpiecznikami [8]

Zastosowanie bezpieczników w sprzęgle ogranicza wartość przenoszonego momentu obrotowego do wartości, po której przekroczeniu następuje ich ścięcie, a w konsekwencji rozłączenie napędu. 
Element podatny sprzęgła Raptor składa się z dwóch części. Wykonany jest z kauczuku naturalnego i posiada specjalną konstrukcję zapewniającą mu dużą wytrzymałość w newralgicznych miejscach. Podatność skrętna tego typu sprzęgieł wynosi aż kilkadziesiąt stopni.

Jak już wspomniano, sprzęgła z wkładkami elastycznymi mają wiele wad. Przede wszystkim nie zabezpieczają w pełni elementów układu napędowego przed przeciążeniem oraz nie spełniają oczekiwań podczas tzw. ciężkiego rozruchu, co może prowadzić do niemożności uruchomienia przenośnika bez jego wcześniejszego częściowego rozładowania. W związku z tym w polskim górnictwie szerokie zastosowanie znalazły sprzęła hydrodynamiczne.

Sprzęgła hydrodynamiczne są to złożone układy, w których przeniesienie momentu obrotowego z członu czynnego (zwanego wirnikiem pompowym) na człon bierny (zwany wirnikiem turbinowym) odbywa się za pomocą łącnika w postaci cieczy [11-12]. Stosowane są głównie sprzęgła o stałym napełnieniu z komorą opóźniającą lub bez niej oraz przepływowe [9].

Dla przenośników, gdzie spodziewany jest ciężki rozruch, znalazły zastosowanie przede wszystkim sprzęgła hydrokinetyczne o stałym napełnieniu z komorą opóźniającą. Zadaniem dodatkowych komór jest zgromadzenie części płynu z komory roboczej, dzięki czemu jest go odpowiednio mniej. Ostatecznie uzyskuje się prawie bezobciążeniowy rozruch silnika przenośnika. Potentatem w produkcji takich sprzęgiel jest firma Voith Turbo GmbH ze sprzęgłami typu TV. Dostawcami tego typu sprzęgieł na polski rynek są ponadto takie firmy jak Flender-Siemens ze sprzęgłami typu FV i FN oraz w najbliższej przyszłości Fasing (MOJ). Na rysunku 13

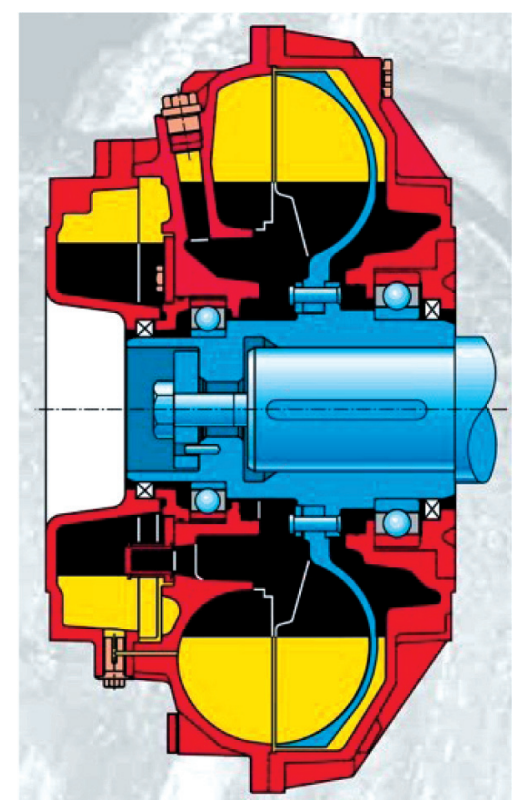

Rys. 13. Sprzeglo typu 487650 TVF firmy Voith [12] przedstawiono budowę jednego sprzęgła $\mathrm{z}$ serii firmy Voith typu 487650 TVF. Sprzęgła tej firmy budowane sa w kilkunastu typach, dostosowanych do szczególnych warunków pracy maszyn roboczych. Różni je głównie budowa i wielkość komór opóźniających.

Sprzęgła hydrodynamiczne o stałym napełnieniu posiadają zabezpieczenie w postaci korków topikowych. Zadaniem ich jest zabezpieczenie przed termicznym przegrzaniem sprzęła oraz nadmiernym wzrostem ciśnienia przez wypuszczenie płynu roboczego.

Oprócz sprzęgieł hydrodynamicznych o stałym wypełnieniu cieczą w mocno obciążonych przenośnikach stosowane są sprzęgła o regulowanym stopniu napełnienia przestrzeni roboczej wodą. Przykład budowy takiego sprzęgła przedstawia rysunek 14 [13].

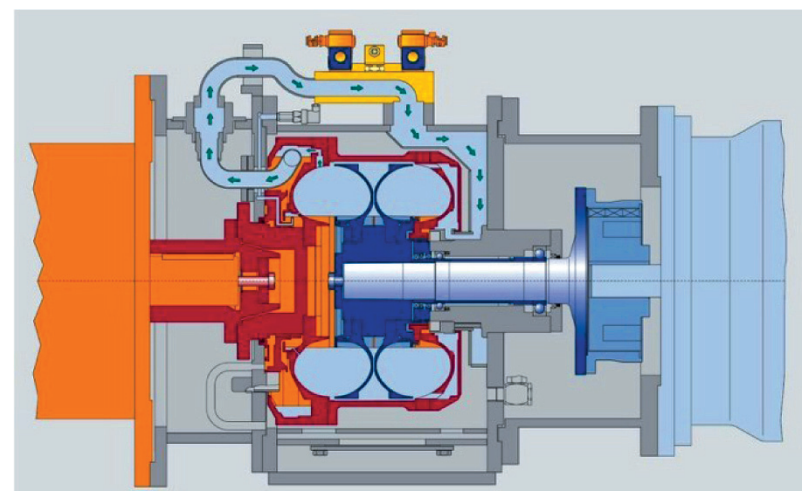

Rys. 14. Sprzegło hydrodynamiczne o regulowanym napetnieniu woda DTPKWL 2 [13]

Początkowa faza rozruchu układu napędowego z takim sprzęgłem odbywa się bez obciążenia (przy sprzęgle opróżnionym). Ciecz hydrauliczna jest doprowadzona dopiero po pełnym rozruchu silnika i od tej chwili następuje powolny rozruch przenośnika zgrzebłowego.

Ścianowy przenośnik zgrzebłowy wyposażony w sprzęgła hydrodynamiczne o regulowanym napełnieniu po uzyskaniu przez łańcuch zgrzebłowy prędkości roboczej przechodzi w stan pracy ustalonej. Za optymalne uznaje się wypełnienie przestrzeni roboczej w granicach $70-75 \%$ całkowitej pojemności sprzęgła przy pracy ustalonej przenośnika [14].

W przypadku stosowania takiego rodzaju sprzęgieł prędkość roboczą łańcuch zgrzebłowy osiąga po około $30 \mathrm{~s}$ od uruchomienia, co przy częstych rozruchach jest czasem zbyt długim. Stanowi to istotną wadę tego typu sprzęgieł hydrodynamicznych.

W przypadku mocno obciążonych przenośników zgrzebłowych, gdzie spodziewane są częste i ciężkie rozruchy, mogą być stosowane sprzęgła przepływowe 
typu DTPW [9]. Konstrukcja tego typu sprzęgieł została wspólnie opracowana przez firmy Voith oraz JOY. W sprzęgle tym następuje ciągła wymiana wody, która najczęściej pochodzi z rurociągu przeciwpożarowego. Jej objętość w komorze roboczej sprzęgła jest ciągle regulowana w zależności od stanu obciążenia przenośnika. Sprzęgło to może pracować z około dwa razy większym poślizgiem niż sprzęgło o stałym napełnieniu.

Podsumowując, sprzęgła hydrodynamiczne są konstrukcją często stosowaną w praktyce eksploatacyjnej od kilkudziesięciu lat. Charakteryzuje je szereg zalet, lecz ich użytkowanie nie jest pozbawione sporej liczby wad. Dlatego też firmy produkujące sprzęgła dla branży wydobywczej poszukiwały nowych rozwiązań.

Firma Halbach-Braun zaproponowała konstrukcje wielopłytkowego sprzęgła przeciążeniowego (sprzęgło poślizgowe). Można je montować pomiędzy silnikiem i przekładnią, a także na wale biernym przekładni.

Sprzęgła tego typu przy umieszczeniu pomiędzy silnikiem a przekładnią łączy się szeregowo ze sprzęgłem elastycznym, np. wkładkowym. Sprzęła te spotyka się jednak bardzo rzadko w krajowym przemyśle wydobywczym [9].

Podobne rozwiązanie stosuje również firma Voith w swych sprzęgłach przeciążeniowych serii SafeSet (rys. 15). Są one wykorzystywane przede wszystkim w przenośnikach zgrzebłowych amerykańskiego producenta maszyn górniczych Joy Mining Machinery. W tym przypadku również dochodzi do poślizgu w mechanizmie sprzęgła. Regulacja momentu, w którym on następuje, odbywa się w układzie hydraulicznym.

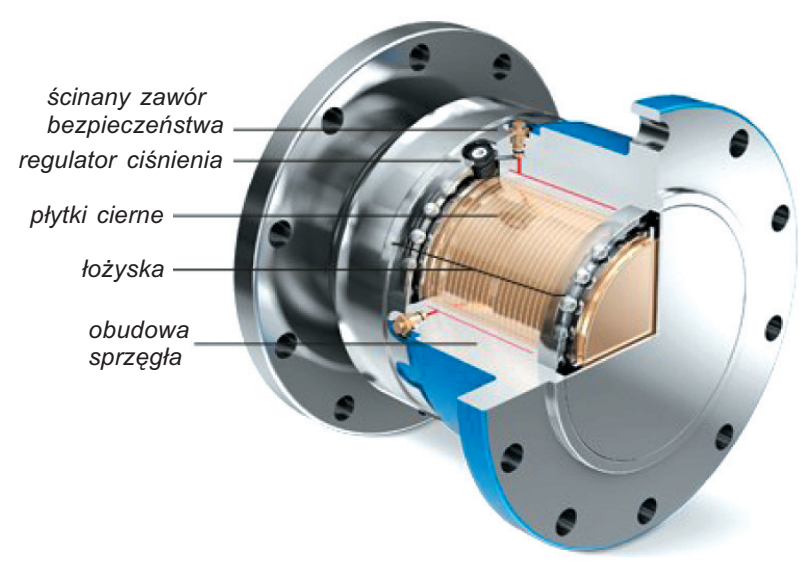

Rys. 15. Budowa sprzegła przeciażeniowego SafeSet firmy Voith [15]

Do bardziej zaawansowanych sposobów zabezpieczania układów napędowych przed przeciążeniem, trudnym rozruchem oraz wyrównującym obciążenie poszczególnych napędów w ścianowym przenośniku zgrzebłowym służą systemy Safesydor firmy Dorstener oraz CST firm DBT i Dodge. W obu rozwiązaniach elementy zabezpieczające zostały bezpośrednio powiązane z przekładnią.

W pierwszym $\mathrm{z}$ wymienionych rozwiązań koło o uzębieniu wewnętrznym pierwszego stopnia planetarnego zostało powiązane ze sprzęgłem wielopłytkowym smarowanym olejem (rys. 16).

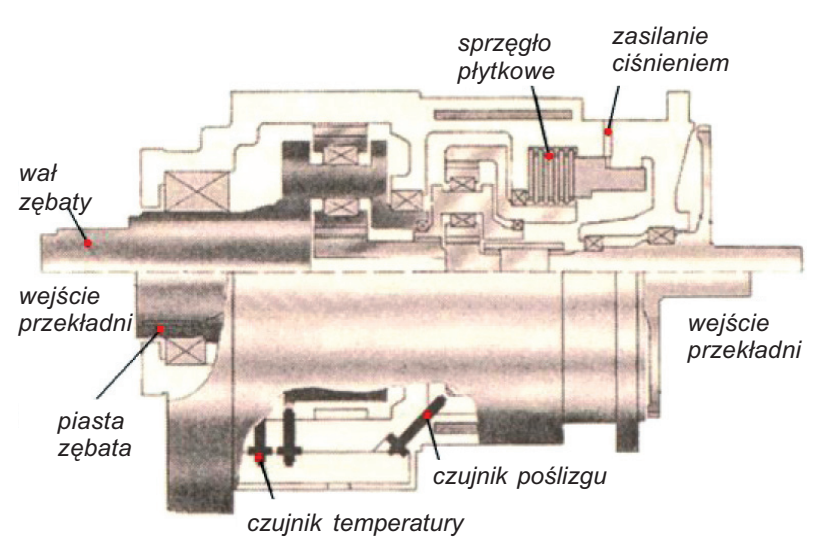

Rys. 16. System Safesydor firmy Dorstener [9]

Rozwiązanie to umożliwia zarówno łatwy rozruch przenośnika, a także zabezpiecza układ napędowy przed przeciążeniami w trakcie pracy ustalonej. Dodatkowo pozwala na wyrównywanie mocy poszczególnych silników napędowych.

System ten nie znalazł jednak większego zastosowania w praktyce kopalnianej [9]. Do jego wad należy wysoki koszt produkcji powiązany ze skomplikowanym systemem sterowania, a także zła współpraca z silnikami dwubiegowymi.

W napędach przenośników zgrzebłowych od połowy lat dziewięćdziesiątych XX wieku znalazł zastosowanie system CST (Control Start Transmission). Wbrew nazwie rozwiązanie to nie służy jedynie ułatwieniu startu przenośnika, lecz przez system sterowania i powiązane $\mathrm{z}$ nim układy czujników jest w stanie reagować na wszelkie zmiany obciążenia przenośnika.

Podobnie jak przy systemie Safesydor, układ napędowy CST stanowi połączenie dwóch podzespołów układu napędowego, przekładni i sprzęgła. Umieszczone są one w dwóch zespolonych na stałe częściach wspólnej obudowy. W jednej części znajduje się przekładnia planetarna $\mathrm{z}$ wbudowanym sprzęgłem CST, osadzonym na wale wyjściowym. Jest to mokre sprzęgło wielopłytkowe ze specjalnymi wykładzinami ceramicznymi (rys. 17). 


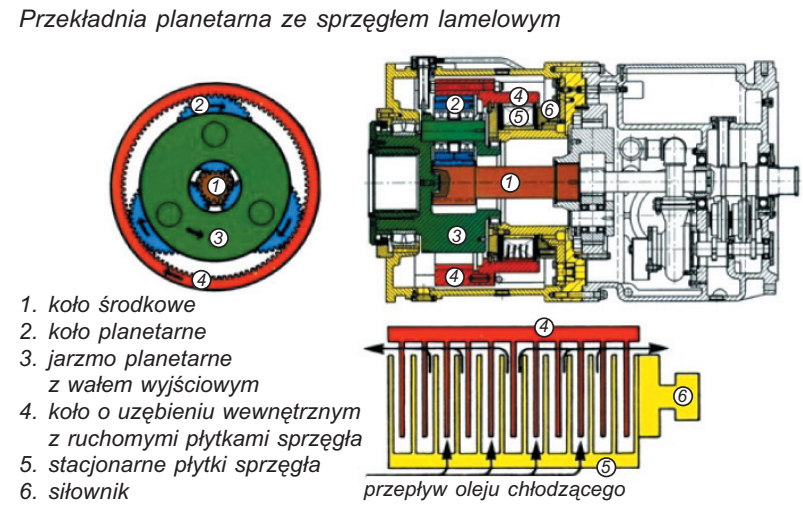

\section{Rys. 17. Budowa zintegrowanego uktadu CST [16]}

W drugiej części obudowy (kolor szary na rys. 16) znajdują się pozostałe elementy systemu, takie jak:

- pompa wysokiego ciśnienia, wymiennik ciepła chłodzący olej;

- sterowanie hydrauliczne, filtr dokładny serwozaworu z płynną regulacją;

- czujnik ciśnienia, temperatury, prędkości obrotowej wejściowej i wyjściowej;

- układ elektroniczny wstępnej obróbki mierzonych wartości;

- sterownik napędowy PROTEC.

W fazie początkowej rozruchu następuje kolejno uruchomienie wszystkich silników napędowych przenośnika zgrzebłowego. Odbywa się to bez obciążenia. Dopiero po ich całkowitym uruchomieniu do sprzęgła systemu CST doprowadzany jest olej pod ciśnieniem. Podczas tej fazy rozbiegowej następuje synchronizacja wzrostu ciśnienia oleju i tym samym obciążenia silnika. W przypadku wystąpienia różnic w poborze mocy w napędzie mniej obciążonym następuje podwyższenie ciśnienia, wskutek czego wzrasta docisk tarcz sprzęgła i zmniejsza się poślizg, aż do chwili wyrównania obciążeń. Natomiast w przypadku zablokowania napędu przenośnika sterownik urządzenia nakazuje odpowiednim elementom wykonawczym całkowite rozłączenie wszystkich napędów.

System CST oprócz niewątpliwych zalet, wynikających z wymienionych powyżej możliwości, ma również wady, które sprawiły, że nie jest on powszechnie wykorzystywany w polskim górnictwie. Rozwiązanie to charakteryzuje się bowiem dość skomplikowaną konstrukcją, która rzutuje na cenę jego wytworzenia oraz koszty obsługi technicznej [17]. Nie bez znaczenia są również wysokie wymagania co do kultury technicznej użytkowania [9]. Te negatywne cechy sprawiły, że rozwiązanie to jest o wiele rzadziej stosowane w porównaniu ze sprzęgłami hydrodynamicznymi.
Opisane do tej pory konstrukcje sprzęgieł wykorzystywanych w górniczych przenośnikach zgrzebłowych mają zarówno wiele zalet, jak i wad. „Starsze” konstrukcje odznaczają się prostotą oraz niskimi kosztami produkcji i eksploatacji. Nie spełniają one jednak szeregu oczekiwań, jakie się przed nimi stawia. „Nowsze” konstrukcje sprzęgieł spełniają wymagania, natomiast wyróżnia je coraz większy stopień złożoności budowy, co podnosi ich koszty wytworzenia oraz obsługi. Dlatego też należy poszukiwać nowych rozwiązań konstrukcyjnych sprzęgieł łączących pozytywne cechy opisanych powyżej. Takim krokiem jest np. konstrukcja tzw. metalowego sprzęgła podatnego skrętnie, które zostało opracowane w Katedrze Mechanizacji i Robotyzacji Górnictwa Wydziału Górnictwa i Geologii Politechniki Śląskiej.

W skład tego sprzęgła wchodzą elementy wykonane całkowicie $\mathrm{z}$ metalu, co stanowi istotną różnicę $\mathrm{w}$ porównaniu $\mathrm{z}$ aktualnie produkowanymi konstrukcjami. Jego idea, budowa oraz zasada działania zostały opisane m.in. w następujących pozycjach literaturowych [18-20]. Charakteryzuje się ono prostotą budowy, a co za tym idzie niskim kosztem wytworzenia.

Na rysunku 18 przedstawiono widok sprzęgła zaprojektowanego dla układu napędowego o mocy silnika elektrycznego $400 \mathrm{~kW}$. Jest ono zintegrowane ze sprzęgłem wkładkowym i umieszczone pomiędzy silnikiem i przekładnią.

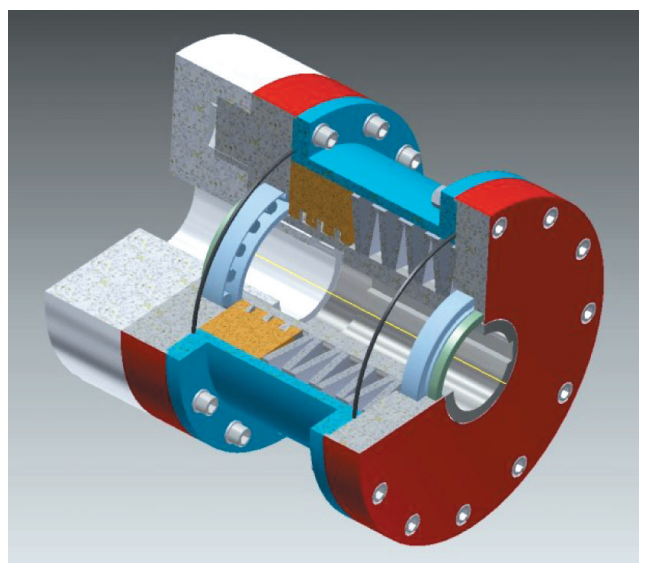

Rys. 18. Widok modelu brytowego metalowego sprzegta zaprojektowanego dla układu napędowego przenośnika zgrzebłowego o mocy napędu $400 \mathrm{~kW}$

Mechanizm metalowego sprzęgła podatnego skrętnie może być również umieszczony w bębnie napędowym (rys. 19).

Zintegrowanie dwóch podzespołów układu napędowego w jednej bryle wprowadza oszczędność miejsca. Jest to rozwiązanie oryginalne, niestosowane do tej pory. 


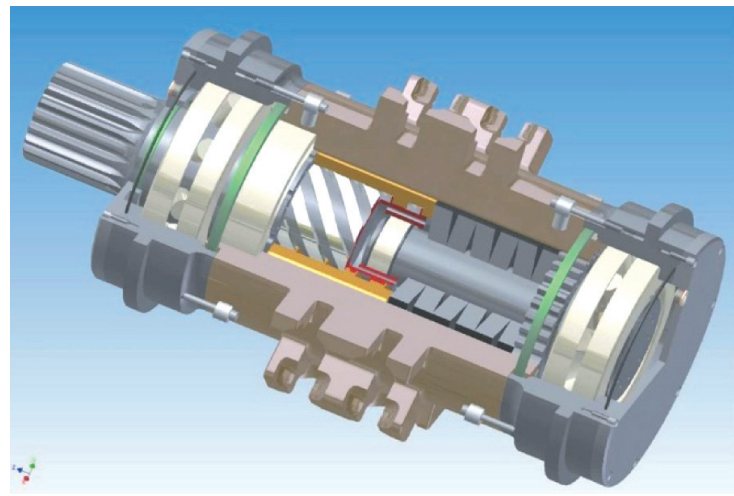

Rys. 19. Sprzegło metalowe podatne skrętnie zintegrowane z bębnem napędowym przenośnika zgrzebtowego (moc napędu $400 \mathrm{~kW}$ )

Pośrednim zabezpieczeniem układu napędowego przed przeciążeniem jest również zapewnienie właściwej współpracy łańcucha zgrzebłowego z bębnem łańcuchowym. Rozwiązanie tego problemu zostało opracowane w Katedrze Mechanizacji i Robotyzacji Górnictwa Wydziału Górnictwa i Geologii Politechniki Śląskiej. Opory ruchu oraz drgania wynikające z przemieszczania się urobku w rynnach są powodem wydłużeń sprężystych łańcucha. Konsekwencją tego zjawiska są zakłócenia w eksploatacji przenośnika spowodowane niewłaściwą współpracą bębna z łańcuchem w miejscu jego zbiegania. Rozwiązaniem tego problemu jest stosowanie nadążnego dostosowania wymaganego napięcia wstępnego łańcuchów do warunków eksploatacji przenośnika. Odbywa się to przez przesuwanie kadłuba napędu pomocniczego z wykorzystaniem odpowiedniego algorytmu sterowania o nazwie ASTEN [21].

\subsection{Przenośniki taśmowe}

Przenośniki taśmowe po przenośnikach zgrzebłowych stanowią kolejny element ciągu transportującego urobek z przodka ścianowego.

W układzie napędowym przenośnika jako element zabezpieczenia układu napędowego przed przeciążeniem, które występuje głównie podczas rozruchu, są stosowane następujące rozwiązania techniczne [22]:

- silniki dwubiegowe,

- rozruszniki tyrystorowe,

- przemienniki częstotliwości,

- wykorzystanie silnika prądu stałego,

- sprzęgła elastyczne,

- sprzęgło hydrodynamiczne,

- system CST.

Podobnie jak w układach napędowych przenośników zgrzebłowych, rozruch przenośnika taśmowego jest możliwy dzięki zastosowaniu odpowiednich urządzeń rozruchowych. Urządzenia te wspierają fazę rozruchu przenośnika sposobem elektrycznym lub mechanicznym.

Wspomaganie procesu rozruchu w sposób mechaniczny odbywa się za pomocą mechanizmu sprzęgła. Najprostszym rozwiązaniem jest zastosowanie sprzęgła elastycznego, jednak nie nadaje się ono do przenośników długich i o bardzo dużej bezwładności. Mała podatność skrętna takiego sprzęgła sprawia, że zmniejsza się zdolność uruchomienia załadowanego przenośnika.

W przenośnikach taśmowych wykorzystywane są również sprzęgła hydrodynamiczne, najczęściej o stałym napełnieniu. Są to sprzęgła firmy Voith systemu T, TV, TVV, TVVS [22]. Stosowane mogą być również sprzęgła przepływowe o regulowanym napełnieniu systemu TPKL (rys. 20) i DTPKL lub ich odmiany [22].

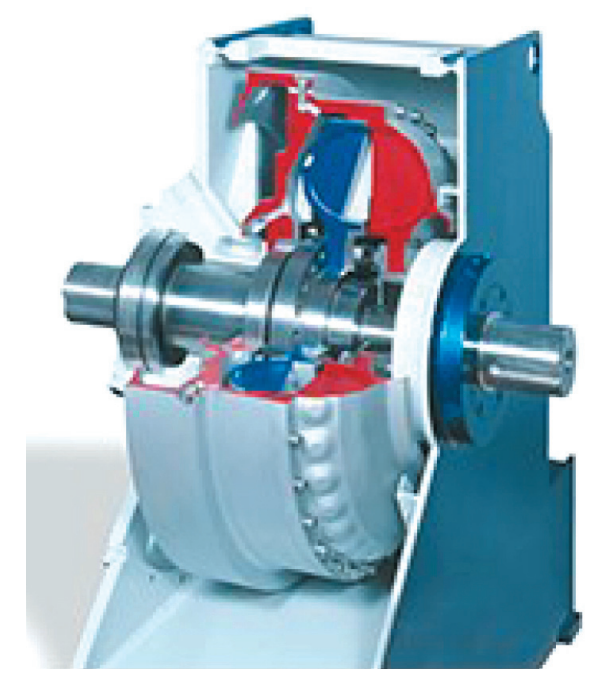

Rys. 20. Sprzegło przeplywowe TPKL firmy Voith [15]

Do rozruchu przenośników taśmowych wielonapędowych o znacznej długości i bezwładności stosuje się opisane wyżej systemy o sztucznej inteligencji CST [22]. System ten dobrze nadaje się do współpracy z tego samego typu napędami w przenośniku wyposażonym w bębnowe napędy pośrednie, gdzie prawidłowe usytuowanie napędu o identycznych mocach silników jest bardzo trudne.

\section{PODSUMOWANIE}

Maszyny wykorzystywane w górnictwie podziemnym pracują w szczególnie trudnych warunkach roboczych oraz środowiskowych. Odnosi się to przede wszystkim do maszyn urabiających oraz transportujących urobek. Dodatkowo nowoczesne górnictwo 
stawia przed nimi szczególnie trudne wymagania, bowiem mają się one charakteryzować dużą niezawodnością oraz znaczną trwałością. Od ich bezawaryjnej pracy zależy ciagłość wydobycia w zakładzie górniczym.

Ciągły wzrost efektywności procesów technologicznych w górnictwie podziemnym, czyli wydajności maszyn wchodzących w cykl wydobywczy sprawia, że najbardziej narażony na dynamicznie zmieniające się obciążenie podczas pracy jest układ napędowy, który stanowi najważniejszy podzespół każdej maszyny górniczej. Od jego działania zależy efektywność danej maszyny.

Sposobem łagodzenia tych niekorzystnych warunków eksploatacyjnych maszyn urabiajacych i transportujących urobek w wyrobiskach chodnikowych może być zastosowanie metod pośrednich i bezpośrednich, które mają na celu zabezpieczenie przed przeciążeniem występującym podczas fazy rozruchu oraz pracy ustalonej.

Metody pośrednie związane są z systemem sterowania, gdzie kontrolowane są parametry silników, nie dopuszczając do ich zablokowania i przegrzania.

W metodach bezpośrednich stosowane są przede wszystkim sprzęgła różnych konstrukcji. Sprzęgła wkładkowe składają się z trwałych podzespołów i posiadaja prostą budowę oraz zasadę działania, lecz mają sporo ograniczeń. Bardziej zaawansowane systemy, np. CST, Safesydor oraz popularne sprzęgła hydrodynamiczne cechują się wieloma zaletami, ale nie są też wolne od wad. Dlatego wciąż poszukuje się nowych rozwiązań. Jednym z nich może być opracowane w Katedrze Mechanizacji i Robotyzacji Górnictwa Wydziału Górnictwa i Geologii Politechniki Śląskiej metalowe sprzęgło podatne skrętnie. Posiada ono znacznie większą podatność skrętną w porównaniu ze sprzęgłami wkładkowymi, łącząc z nimi prostotę budowy.

\section{Literatura}

[1] Broen A.: Kombajny chodnikowe, Wydawnictwo Śląsk, Katowice 1980.

[2] Dolipski D., Cheluszka P.: Dynamika układu urabiania kombajnu chodnikowego, Wydawnictwo Politechniki Śląskiej, Gliwice 2002.

[3] Świtoński E., Chuchnowski W.: Optymalizacja cech konstrukcyjnych mechatronicznych układów napędowych maszyn górniczych, „Maszyny Górnicze” 2008, 4: 23-30.

[4] Rupik J., Skrzypiec A., Kurek M.: Doświadczenia eksploatacyjne napędów maszyn przeznaczonych dla górnictwa od hydraulicznych do elektrycznych, „IV Szkoła Mechanizacji i Automatyzacji Górnictwa”, Szczyrk 2008.

[5] Suchoszek J., Nogas Z.: Wspótpraca DAMEL-u z ZZM S.A., Sympozjum z okazji 60-lecia Zabrzańskich Zakładów Mechanicznych S.A., Zabrze 2007.
[6] Grzesica P.: Wpływ obciązenia zewnętrznego na sity międzyzębne $w$ przekładniach zebatych maszyn górniczych, Wydawnictwo Politechniki Śląskiej, Gliwice 2011.

[7] Sprzęła elastyczne typu SP, dokumentacja techniczno-ruchowa, MOJ S.A. (Grupa Fasing), Katowice 2013.

[8] Oferta firmy Fabryka Elementów Napędowych FENA, Katowice 2017.

[9] Suchoń J.: Górnicze przenośniki zgrzebłowe. Budowa i zastosowanie, Instytut Techniki Górniczej KOMAG, Gliwice 2012.

[10] Oferta firmy TZ Polska Sp. z o.o., Bytom.

[11] Antoniak J.: Przepływowe sprzęgła wodne do napędów wysokowydajnych ścianowych przenośników zgrzebłowych, „Mechanizacja i Automatyzacja Górnictwa” 2002, 11: 21-29.

[12] Start-up Components for Mining, broszura firmy Voith Turbo GmbH \& Co. KG, Crailsheim 2007.

[13] Fill-controlled Fluid Couplings, broszura firmy Voith Turbo GmbH \& Co. KG, Crailsheim 2007.

[14] Antoniak J.: Urzadzenia $i$ systemy transportu podziemnego w kopalniach, Wydawnictwo Śląsk, Katowice 1990.

[15] Oferta firmy Voith GmbH \& Co, Niemcy 2017.

[16] Zintegrowany układ napędowy $W B / C S T$, broszura firmy DBT GmbH, Lünen 2000.

[17] Mendyka P.: Układy rozruchowe ścianowych przenośników zgrzebłowych, „Napedy i Sterowanie” 2014, 7/8: 138-144.

[18] Filipowicz K.: Doświadczalna i teoretyczna identyfikacja cech dynamicznych nowej konstrukcji sprzegła podatnego $w$ zastosowaniu do układu napędowego maszyn górniczych, Wydawnictwo Politechniki Ślaskiej, Gliwice 2009.

[19] Filipowicz K., Kuczaj M.: Wpływ metalowego sprzęła podatnego skrętnie na prace układu napędowego przenośnika zgrzebłowego. XXIII Międzynarodowa Konferencja Naukowo-Techniczna „Trwałość Elementów i Węzłów Konstrukcyjnych Maszyn Górniczych TEMAG” 2015: 19-30.

[20] Kuczaj M., Filipowicz K.: Badania symulacyjne wptywu metalowego sprzęgła podatnego skrętnie na rozruch układu napędowego, XXIII Międzynarodowa Konferencja Naukowo-Techniczna „Trwałość Elementów i Węzłów Konstrukcyjnych Maszyn Górniczych TEMAG” 2015: 89-98.

[21] Dolipski M., Cheluszka P., Remiorz E., Sobota P.: Innowacyjne górnicze przenośniki zgrzebłowe, Wydawnictwo Politechniki Śląskiej, Gliwice 2017.

[22] Antoniak J.: Przenośniki taśmowe: wprowadzenie do teorii $i$ obliczenia, Wydawnictwo Politechniki Śląskiej, Gliwice 2004.

dr hab. inż. KRZYSZTOF FILIPOWICZ dr inż. MARIUSZ KUCZAJ dr inz. MACIEJ KWAŚNY

Katedra Mechanizacji i Robotyzacji Górnictwa Wydziat Górnictwa i Geologii Politechnika Ślaska ul. Akademicka 2, 44-100 Gliwice $\{$ krzysztof.filipowicz, mariusz.kuczaj, maciej.kwasny\}@polsl.pl

dr inz. KRZYSZTOF TWARDOCH Instytut Podstaw Budowy Maszyn Wydziat Samochodów i Maszyn Roboczych Politechnika Warszawska ul. Narbutta 84,02-524 Warszawa krzysztof.twardoch@simr.pw.edu.pl 